Portland State University

PDXScholar

6-29-1995

\title{
North vs. South: Sovereign Equality and the Environment in the Twentieth Century
}

Thomas Schlesinger

Portland State University

Follow this and additional works at: https://pdxscholar.library.pdx.edu/open_access_etds

Part of the Political Science Commons

Let us know how access to this document benefits you.

\section{Recommended Citation}

Schlesinger, Thomas, "North vs. South: Sovereign Equality and the Environment in the Twentieth Century" (1995). Dissertations and Theses. Paper 5048.

https://doi.org/10.15760/etd.6924

This Thesis is brought to you for free and open access. It has been accepted for inclusion in Dissertations and Theses by an authorized administrator of PDXScholar. Please contact us if we can make this document more accessible: pdxscholar@pdx.edu. 


\section{THESIS APPROVAL}

The abstract and thesis of Thomas Schlesinger for the Master of Science in Political science were presented on June 29 , 1995, and accepted by the thesis committee and the department.

COMMITTEE APPROVALS:

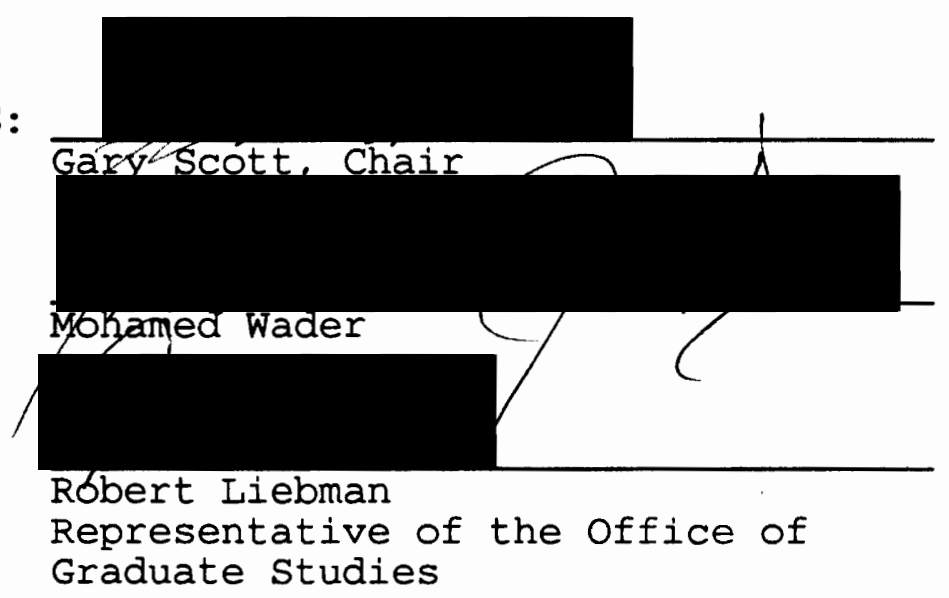

DEPARTMENT APPROVAL:

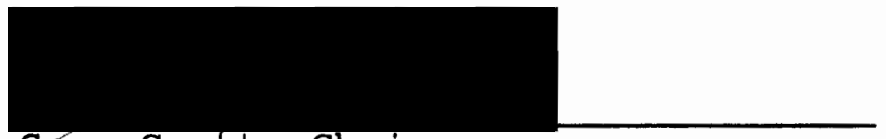

Gary scott, Chair

Department of Political Science

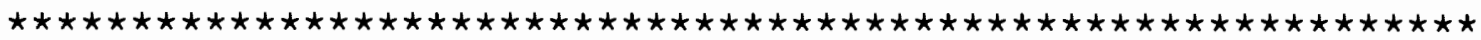

ACCEPTED FOR PORTLAND STATE UNIVERSITY BY THE LIBRARY by on $15 \operatorname{lon} 41995$ 
ABSTRACT

An abstract of the thesis of Thomas Schlesinger for the Master of Science in Political Science presented June 29, 1995.

Title: North vs. South: Sovereign Equality and the Environment in the Twentieth Century.

Although Third World states lack military and economic strength, they still are able to exert considerable influence on certain international issues. The proliferation of small states following world war II, coupled with the twentieth century acceptance of the norm of sovereign equality, has enabled the weak states of the international system to challenge the order established by the strong. While Third World nations are weak according to traditional measures of power, sovereign equality and bloc voting by the small states, have accorded a type of "conditional" power to the south.

This conditional power is augmented by the advent of a new international issue, the environment. Because of their large populations and natural resource bases, developing countries significantly influence environmental problems and therefore have greater leverage in environmental negotiations.

This thesis seeks to demonstrate that because of the military and economic weakness of the South, it has sought to develop alternative sources of international strength. These 
new sources take advantage of norms and issues particular to twentieth century world politics. While these other sources thus far lack the potency of military or economic power, they do provide the South with a limited, but nonetheless important amount of influence in international politics.

This thesis analyzes the nature and scope of the South's power arising out of the acceptance of the norm of sovereign equality. The paper also studies a second source of strength for developing nations, negative power; this power is based on the South's ability to frustrate Northern efforts to deal with serious environmental problems. By examining two major international environmental conferences, the thesis demonstrates both the character and limitations of this negative power. The foregoing study concludes that the new power of the South, though still quite limited today, may be an indication of growing strength as global environmental problems become increasingly central to international relations. 


\title{
NORTH VS. SOUTH : \\ SOVEREIGN EQUALITY AND THE ENVIRONMENT \\ IN THE TWENTIETH CENTURY
}

\section{by}

THOMAS SCHLESINGER

A thesis submitted in partial fulfillment of the requirements for the degree of

\author{
MASTER OF SCIENCE \\ in \\ POLITICAL SCIENCE
}

Portland State University

1995 
TABLE OF CONTENTS

I. CONCEPTS AND TERMINOLOGY 1

II. THE EVOLUTION OF THE CONCEPT OF 34 SOVEREIGN EQUALITY

III. THE EMERGENCE OF THE SOUTH

IV. THE ROLE OF NEGATIVE POWER 71

IN THE OZONE DEPLETION PROBLEM

V. NEGATIVE POWER AND THE GLOBAL WARMING NEGOTIATIONS

$\begin{array}{ll}\text { VI. CONCLUSION } & 113\end{array}$

$\begin{array}{ll}\text { BIBLIOGRAPHY } & 121\end{array}$ 


\section{CHAPTER I \\ CONCEPTS AND TERMINOLOGY}

\section{Introduction}

"The conflict between the North and the South, the powerful and the weak, has become one of the defining characteristics of the present international system."1

-Stephen Krasner

Although Third World states lack military and economic strength, they still are able to exert considerable influence on certain international issues. The proliferation of small states following World War II, coupled with the twentieth century acceptance of the norm of sovereign equality, has enabled the weak states of the international system to challenge the order established by the strong. While Third world nations are weak according to traditional measures of power, sovereign equality and bloc voting by the small states, have accorded a type of "conditional" power to the South." This conditional power is augmented by the advent of a new international issue, the environment. Because of the large population, land area, and natural resources of the South as a whole, it enjoys an unexpectedly strong negotiating position at international environmental conferences. The new power of the South, though still quite limited today, may be an indication of growing strength as global environmental problems become increasingly central to international relations.

Most of the developing nations achieved statehood when the European powers relinquished their colonies following 
World War II. Although granted political autonomy, many of these new states suffered from a lack of size, economic development and political identity. This resulted in the creation of large numbers of small, weak nations. During the cold War ${ }^{3}$, discussions of blocs, polarization, and military power dominated world politics. Although international attention centered on the superpower conflict, Third World nations sought to refocus world concern upon the problems of underdevelopment. The poor called for reforms of the international system to make living standards more equitable. ${ }^{4}$ However, due to their lack of power in world affairs, the developing nations had little success in affecting the international agenda.

The United Nations would provide the international forum for Third World nations to present their problems. ${ }^{5}$ By consistently voting as a group, these nations caused the U.N. to increasingly focus on the subject of development. ${ }^{6}$ The structure of the United Nations exemplifies the tension between conflicting norms in the twentieth century. Great Power primacy is epitomized in the Security Council and the rights of its permanent members. The "democratic" nature of the General Assembly embodies the notion of sovereign equality.

Because of the importance of Third World actions on environmental matters, the increased influence of the south is especially evident in environmental negotiations. Issues 
such as population control, poverty, and pollution can only be addressed through global cooperation. ${ }^{7}$ Because of their populations and natural resources, developing countries significantly influence these problems and therefore have greater leverage in environmental negotiations.

Although the Southern nations have framed their argument for economic reforms along moral lines, political realists view the South's claim as simply a method to increase national power. By linking their developmental problems, with negotiations over environmental problems, the South hopes to increase their power in the international system.

This thesis seeks to demonstrate that because of the military and economic weakness of the South, it has sought to develop alternative sources of international strength. These new sources take advantage of norms and issues particular to twentieth century world politics. While these other sources thus far lack the potency of military or economic power, they do provide the South with a limited, but nonetheless important amount of influence in international politics.

The first part of this thesis will deal with theories of power, bloc politics, sovereign equality, and international organizations. The latter part will trace the development of the new environmental power of the south at two international conferences in the late twentieth century. 


\section{International Objectives \\ of Nation-States}

The hypothesis of this paper contains several underlying assumptions. It assumes that the international system, in Kenneth Waltz's terms, is "decentralized and anarchic."8 Waltz goes on to state that "self-help is necessarily the principle of action in an anarchic system." In such a system, a state may ultimately rely only upon its own resources to ensure its well-being and satisfy its needs.

A variety of needs must be satisfied to ensure the well-being of states, some needs being more basic than others. "Survival is the primary goal of all states, and in the worst situations, force is ultimately necessary to guarantee survival. Thus, military force is always a central component of national power."10 security from external military threat is the most fundamental need of any state in an anarchic system. However, satisfaction of this need usually results in another need assuming primary importance.

Richard Rosecrance differentiates between three classes of international objectives for a state: material, ideological, and security. Material goals include the acquisition of territory, and economic security. Ideological objectives refer to the state's protection of its central beliefs, while security goals allude to the 
continued existence of the state. Employing the image of an onion, Rosecrance ranks the importance of each goal:

\begin{abstract}
- the three international objectives . . material, ideological, and security-constitute a hierarchy in importance and centrality. Material objectives are most peripheral and least important. Ideological objectives are more important than material goals. Under most conditions, protection of a regime's ideology is considered more important than the acquisition of new territory. Still more important than any ideological objective, however, is the overriding goal of state security. If objectives are ranked in this order, it becomes possible to think of an onion of international objectives, with an outer layer of material goals, an inner layer of ideological goals, and a core of security. Security, the most fundamental goal, is sought at the expense of other objectives. ${ }^{11}$
\end{abstract}

Rosecrance goes on to write that as the state meets its core objectives, the other objectives rise in importance. That is, when security is no longer threatened, ideological objectives become the primary goal of the state. If a state attains both its security and ideological objectives, it will seek to improve its material welfare - either through territorial acquisition or economic means. Furthermore, if two goals are in conflict, such as economic well-being and security, the state will always satisfy the more central need. Until the most basic need, the need to survive, is met, it will necessarily dominate all others. ${ }^{12}$

Although the security objective and military power have historically been the primary concern of nations, a number of authors believe that economics is assuming increasing importance in the twentieth century. ${ }^{13}$ According to this 
view, Rosecrance's onion is growing smaller as the distance between the core and outer skin decreases.

During the cold war, the security objective assumed paramount importance. The ideological objective, while also present, was of secondary importance. The East-West axis demarcated the major division in world politics during the Cold war. By the time of its end, the dynamics of world politics would change with the fragmentation of the EastWest blocs and the rising importance of economics as an international objective. The economic division between rich and poor, North and South, had begun to assume greater significance.

\section{Power}

In the anarchic international system, nations compete with other nations to attain the international objectives of security, ideology, and material. A nation's power determines how successful it will be in this pursuit. Strong nations will cope best in a world governed by the rule of self-help; weak states will be at risk in an international system that is based on power politics and free-market economics.

The question is, what is power and how can it be measured? This question is frequently approached from two directions. Power is defined according to its effect or it is operationalized as certain physical attributes. Robert Keohane writes that any definition of power should clearly 
distinguish between power as the ability to influence others' behavior, and power as a measurable resource ${ }^{14}$.

A number of authors have defined power as the ability to influence. John Spanier states that "Power is the capacity to impel the behavior of others in accordance with one's own objectives."15 Additionally he also distinguishes between perceived and actual power, and between the power to prevent (negative power) and the power to compel (positive power). ${ }^{16}$ Marshall Singer describes it as 'the ability to exercise influence and the ability to prevent influence from being exercised over oneself.'17 According to Kenneth waltz, power is the ability to affect others more than be affected by them. ${ }^{18}$

Two of these definitions are particularly applicable for the purposes of this thesis: power as the ability to affect others, and power as the ability to prevent, i.e., negative power. Unlike more powerful states, Southern states cannot buffer themselves from the turbulence of the international system ${ }^{19}$. Their low level of economic development leaves them vulnerable to the vicissitudes of the international economy. Lacking the military or economic power to threaten, the South makes use of a more limited form of power, the power to prevent.

However, there is a difficulty with these sorts of definitions. Such definitions are useful to determine power only after the influence has been exerted; they cannot help 
predict outcomes. A definition based on measurable resources is often a better predictor of outcomes.

A definition of power is much easier to arrive at than that "old bogy--the measurement of national power."20 There is considerable disagreement among authors as to what provides an accurate assessment of national power. Many authors claim that power can be accurately measured by the empirical attributes of a state. David Garnham, in studying violence in the international system, chose to create a power index based on national attributes: geographical area, population, gross national product, electrical power generation, military force levels, and defense expenditures. Bruce Russett and Charles Taylor/Michael Hudson employed some subset of these variables in their studies. ${ }^{21}$

Jeffrey Hart writes that most national power rankings rely on the measurement of physical attributes. ${ }^{22}$ while these attributes have the distinct advantage of being easily quantifiable, he points out some disadvantages of this technique: 1) Actors may not always be able to take advantage of these resources, 2) Different conflicts require different types of resources, 3) Some resources such as will to fight are not easily quantifiable, and 4) the focus on the state level ignores coalitions of states, and nonstate actors. ${ }^{23}$

To overcome some of these problems, political scientists have suggested differing alternatives. Michael 
Ward and Lewis House claim that their method, "behavioral power," 24 is more accurate than the measurement of attributes or capabilities. With this method, the reactions of other nations to a given state's behavior determine the "situational power." However, this method has several disadvantages. It is more subjective, the rankings change rapidly with events, and are useful only after the fact. Contrary to the criticisms of Ward and House, Michael Sullivan claims that although measurement of physical resources may be inaccurate in some short-term situations, "traditional measures of power . . are likely to reflect the changes in these nations' power levels."25

Perhaps Hans Morgenthau is correct when he posits that "the task of assessing the relative power of nations for the present and for the future resolves itself into a series of hunches."26 However, although there may be some inaccuracy in measuring power by physical attributes, it does provide a more objective analysis. Perhaps power is best measured through a combination of the intuitive (definitions) and the observable (physical attributes).

There are different types of power in the international system, military and economic power being two of the most commonly used. Rosecrance's material objective reflects the desire for economic well-being; his security objective reveals the need for security from external military threat. Nations attain these international objectives through the 
use of national power, which itself can be viewed along military or economic lines. However, it is not necessarily true that economic power pursues economic ends while military power pursues military ends. Waltz writes that "The distinction frequently drawn between matters of high and low politics is misplaced. States use economic means for military and political ends, and military and political means for the achievement of economic interests."27

Just as Waltz disparages the traditional subordination of economics to security, Thompson and Rapkin argue that economic power may be more significant today than military power. While this view may be too extreme, it does help point out the increasing importance of conflicts arising out of economics rather than security.

Military power has been the most salient value in the global system for some time. Its closest rival is economic power. . . However, the global system's value hierarchy currently appears to be undergoing substantial change which may result in economic power becoming more important than military power. ${ }^{28}$

The increased salience of economics underscores the significance of the struggle between North and South. Although the dispute between the developed and developing nations is primarily of an economic nature (i.e., it involves the economic objective), it would be a mistake to develop power rankings based solely on economic resources. Military power aids in the pursuit of the economic objective. 
For the purposes of this study, I have chosen to rank states according to two national attributes: military expenditures and gross national product. Although these two indicators are gross measures of power, they serve the purpose here as well as more discriminating ones. In selecting these attributes I hope to measure two independent elements of power in the international system.

Rankings of national power based on measurable attributes usually include some gauge of military power. George Modelski writes that military expenditure "serves as a rough gauge of relative military power, hence also . . . consequent international standing."29 This was of particular importance in assessments of the East-West conflict.

Two of the most common measures of military power are military force level and military expenditure. Military force level is a poor gauge since it fails to capture training or modernization of equipment. On the other hand, total annual military expenditure is one of the best single indices of military power in the international system. ${ }^{30}$

The second attribute, gross national product, is one of the best single indicators of national power. ${ }^{31}$ It is included here as a measure of the total wealth of a nation and accordingly, its influence in the global economic system. Russett cites several studies showing that energy consumption is highly correlated with GNP and yet is 
superior because of the common unit of measure. ${ }^{32}$ For the purpose of producing a gross ranking of power, however, GNP is sufficiently accurate.

In calculating this power index, I ranked each nation according to a single criterion, and then summed the two rankings of each state The states were then ranked according to this new power index. This method is similar to that used by Taylor and Hudson. ${ }^{33}$ while a more sophisticated method could probably have generated interval rather than ordinal data, this is unnecessary since I only need to create a relative ranking of national power. These power rankings measure traditional sources of power -military and economic resources.

The North-South conflict is often characterized as the weak vs. the strong; the ranking produced with these two attributes will aid in analyzing power differentials in this struggle. The gross power ranking also highlights the differing role of power in the East-West and North-South conflicts.

The results of this power assessment are in Table 1 at the end of this chapter. The year 1964 was chosen because it is the date of the first UNCTAD conference, and therefore is often chosen to mark the start of the North-South conflict.

Table 1 reveals a fundamental difference between the East-West conflict and the North-South one. The nations of 
East (Warsaw Pact) and West (NATO) are clustered together in the top quartile of the power ranking. They represent two militarily/economically powerful groups of countries vying for dominance of the international system. The countries of the North ${ }^{34}$, while not actually a clearly defined group, consist of the top quartile of nations. The nations of the South are often identified by their membership in the Group of 77 organization ${ }^{35}$. They comprise the bulk of the lower three quartiles of the list. Whereas East vs. West can be seen as the battle of the strong against the strong, North vs. South is the battle of the strong vs. the weak.

Table 2, below, illustrates the disparity between North and South. The 28 industrialized nations account for 83 percent of world GNP, while 75 developing nations account for only 11 percent. These total GNP figures reflect the complete economic dominance of the developed nations.

TABLE 2

WORLD GNP FIGURES ${ }^{36}$

$\begin{array}{lrr} & \begin{array}{c}\text { Milions } \\ \text { of } \$\end{array} & \begin{array}{c}\text { Percent } \\ \text { of Total }\end{array} \\ \text { Developed Nations (28 nations) } & 1,586,084 & 838 \\ \text { Developing Nations (75 nations) } & 208,530 & 118 \\ \text { Other Nations } & 118,626 & 68\end{array}$

Table 1 ranks nations according to traditional bases of power. It is the supposition of this paper that the appearance of new norms and issues in the twentieth century 
has created the opportunity for states to develop other bases of power. The South's weakness precludes it from challenging the North either militarily or economically. However, the doctrine of sovereign equality presents a new battlefield - the international organization. It is here that the drama of North vs. South is played out.

The Theory of Blocs and Alliances

One of the new types of power of the twentieth century, sovereign equality, is only effective if nations consistently vote as a group in international organizations. Before this paper goes on to explore the question of the North-South blocs, the concept of 'bloc' should be examined. Much of the literature on blocs and alliances describes the East-West situation. The question is, to what degree do these concepts apply to the North-South confrontation?

Blocs and alliances are terms used by political scientists to distinguish between two different types of interstate behavior. In understanding how these concepts are commonly used, a better understanding of phenomena such as the North-South struggle, may be obtained.

The expression, bloc, is probably best explained by distinguishing it from the term alliance. While not all authors share the definitions used here, they will serve as a common point of reference for this paper. Both terms, alliance and bloc, refer to a grouping of states in pursuit of common interests. The word alliance typically describes 
a coalition based on common military goals, while a bloc may form around other issues such as trade, development, or environment. ${ }^{37}$

Blocs and alliances may be distinguished by the fluidity of their memberships. Alliances are more temporary than blocs because they are based on the short-term interests of the individual states. If and when an alliance is no longer in the interest of a given state, that state will withdraw from the coalition. Morton Kaplan believes that the formation of shifting alliances had helped to maintain the stability and peace of the international system. ${ }^{38}$ These shifting alliances characterized the preWorld War I system that Kaplan referred to as the Balance of Power system. ${ }^{39}$

Unlike membership in alliances, bloc membership is more permanent. ${ }^{40}$ Blocs are bound together unconditionally, ostensibly by some common concept such as ideology. In a system composed of blocs, "groupings will depend upon longrange rather than upon short-term interests."41

Because of their rigidity, blocs may fail to reflect the differing interests of their members. Robert Rothstein writes that membership patterns emphasize "bloc solidarity even at the cost of national interests."42 Blocs are not natural phenomenon in an anarchic political system. They do not always allow sovereign states to act in their own best interests and therefore are most likely to exist only when 
states perceive the core objective of security to be threatened.

$$
\begin{gathered}
\text { The Historical Development } \\
\text { of Blocs }
\end{gathered}
$$

The development of political blocs is a twentieth century phenomenon. International relations based on balance of power politics precludes the existence of blocs; in a balance of power situation, states will temporarily align with other states according to their interests at a given time.

The flexible nature of pre-World war I international politics was commonly thought to have maintained peace. ${ }^{43}$ But the recurrence of another world war discredited balanceof-power politics as a source of international stability. Following the war, international politics based on ideology replaced balance of power politics. Richard Rosecrance writes: "The notion that international politics could not be conducted on balance-of-power assumptions comported well with the ideological character of the post-World War II age." 44

In an ideological battle, each side is implacably opposed to the other and that for which it stands; the fixed nature of blocs renders balance of power politics inoperable. Thus, the ability to create a multipolar balance of power by creating coalitions of states, ended with the emergence of two superpowers following World war II..$^{45}$ 
The burdens of the second world war exacted a heavy toll on the European powers. The multipolar world that they had dominated was at an end. Their need for colonial resources during world war II and their weakness after the war, encouraged colonial demands for an end to European rule. The U.S. favored decolonization and selfdetermination, and feared that stifled liberation movements could fall under Communist influence. ${ }^{46}$ It pressured its allies to at least institute reforms in their colonial empires.

The turbulence of decolonization created an opportunity for the superpowers to convert nations to their bloc. Paul Kennedy refers to this worldwide division into East and west as the "steady, lateral escalation from Europe itself into the rest of the world."47 As bloc members interacted more with fellow members than members of the rival bloc, the blocs came to be self-contained.

Accompanying the appearance of the cold war was the division of the world into two hostile camps separated by an ideological divide.. . [that] conflict was not mitigated by any other cleavages cutting across the line dividing the two blocs. Thus the conflict was severe, and the use of shifting alliances to redress imbalances of power between coalitions was no longer possible. Some people used the term "bipolarity" to characterize the situation. ${ }^{48}$

Although lesser powers could not affect power dynamics, they felt the need to choose sides in the struggle, and the superpowers sought to increase the number of nations in 
their respective blocs. In 1968 at the height of the cold War, Robert Rothstein wrote, "Small Powers are now sought as symbols of victory in a political struggle which is never destined to erupt into Great Power conflict."49 During the superpower struggle, victories were won when a nation chose to align with one bloc or the other.

The blocs that developed in the cold war era reflected two rival military/economic centers, each predominantly self-contained. Each saw the other as a threat to their ideological and core security objectives. Faced with a threat to their core objectives, member nations sometimes sacrificed individual interests for the sake of the bloc. The concepts of blocs and alliances as used during the Cold War, do not apply to the North-South groupings. These groups are not alliances. They lack any military nature, and the Third World has existed too long to be characterized as a short-term coalition. While the North and South are commonly referred to as blocs, they are not blocs like those of the East and West. Although they have a semi-permanent aspect, the North-South blocs lack the solidarity that distinguished the East-West blocs.

Bloc behavior can be seen in terms of Rosecrance's onion theory. The members accepted the leadership of the hegemon because of the threat to their innermost objective security. In the case of North vs. South, neither side feels its existence threatened. The East-West contest, in 
addition to the security threat, involved an ideological threat. Each bloc sought to maintain their core ideologies (Communism and capitalism) in the face of an external threat.

The ideological struggle is less clearly defined in the North-South debate. Dependency Theory, ${ }^{50}$ adopted by the South, is not an ideology in the sense of capitalism (the West) or Communism (the East). The theory does not constitute an integral part of the South's existence. While Dependency Theory does call for major reforms of the free market system, the South lacks the power to change the system itself and the North largely rejected the reforms as unworkable or undesirable. ${ }^{51}$

In the absence of security or ideological causes, the North-South struggle occurs at the material-economic level. Because material interests are less central to a state's interests, they are unlikely to result in the creation of cohesive blocs. Nations are less inclined to sacrifice their own interests for the greater good of the bloc without a threat to their military security.

Rather than speak of the South as an alliance or bloc, Marc Williams describes it as a pressure group. He writes that pressure groups are relatively new in the international system.

A pressure group can be thought of as a collection of states (individuals etc.) applying pressure as a political device to secure a change (or the maintenance 
of the status quo) on a particular set of issues. In this respect the $\mathrm{G77}$ is a pressure group exerting pressure for the reform of the international economic system, the creation of new international regimes and the transfer of resources from rich states to poor ones. ${ }^{52}$

North and South behave more like pressure groups than the military/economic blocs that characterized the cold war. If they can be considered any kind of bloc, they are a voting bloc. Voting blocs are more transitory and may change according to the issue. Military blocs enhance the power of their members due to their additive nature. In just the same way, voting blocs increase the power of member nations. In a world that accepts sovereign equality, the combined voting strength of the Third World nations, provides them with a limited and conditional sort of power. of course, powerful states may also vote in blocs although there is somewhat less need to do so. By their nature, powerful states have power resources in addition to voting strength and may choose to rely on these more traditional bases to achieve their ends.

Polarity and Polarization

The terms bipolarity and bipolarization have been used to describe the structure of the international system following World War II. Although often used interchangeably, William Thompson and David Rapkin make a useful distinction between the concepts: "the fundamental problem with previous treatments of polarity and 
polarization has been the failure to differentiate a system's distribution of power (polarity) from the tendency of actors to cluster around the most powerful states in the system (polarization)."53

This differentiation is needed to describe two different aspects of a system dominated by a pair of states. Polarity refers to the number of different poles or powerful states in the system. ${ }^{54}$ Therefore, bipolarity refers to a world with two dominant states; multipolarity implies at least three. Because the appearance of two world hegemons and the formation of two rival blocs occurred nearly concurrently, there is some confusion as to which represents the cause of bipolarity. Both Kenneth and Morton Kaplan argue that it is the presence of predominant powers that creates polarity, not the clustering of nations. Blocs of nations may or may not be formed about the superpowers. ${ }^{55}$ Polarity can be established by studying the number of states in the system and the types of alliances that they form. Polarization is somewhat more difficult and different authors have suggested various ways to assess it.

Thompson and Rapkin claim that polarization describes "the direction and magnitude of the interactions among polar and nonpolar units."156 After studying the literature, they claim that there are three different ways to measure polarization: the number of bonds, the number of transactions, or the type of interaction. ${ }^{57}$ 
Measurement by bonds assesses the number of longlasting relationships (alliances, diplomatic exchanges, and IGO membership) within a bloc and compares this number with that between blocs. Measurement by transactions assesses polarization in terms of the amount of trade and financial aid flowing between countries. Measurement by the degree of interaction evaluates the degree and type of interaction among states, the greater the polarization of the system, the greater the intrabloc interaction (and the less interbloc interaction). ${ }^{58}$

Polarity, as defined earlier, is based on the number of dominant states in the system. Given the fact that the South lacks a hegemon ${ }^{59}$, according to this definition, it cannot be a pole, and the North-South division cannot be a bipolar one. In the absence of polarity, the concept of polarization makes less sense. The three types of measurement for polarization (bond, transaction, and interaction) were designed for a world polarized between two near equals. They are oriented toward the conventional measures of power - military and economic.

All three are poor measures of polarization in the North-South conflict because of the inequality of the two sides. Polarization is characterized by increased intrabloc and decreased interbloc activity. However, the wealth and the military power of the North dictates that most interstate relationships are North-North and North-South, 
fewer are South-South. Because of the South's economic dependence upon the North, the South lacks the sort of selfcontained bloc activity that was characteristic of polarization. ${ }^{60}$ Just as North and South cannot qualify as blocs in the Cold War sense, neither do they describe a bipolar or a polarized world.

Morton Kaplan:

Great Power Primacy and Sovereign Equality

One of the most interesting and thoroughly developed theories concerning alliances, blocs, and polarity is the work of Morton Kaplan. ${ }^{61}$ He formulates a theory of six different distributions of power in the international system. These different models depict power distributions in the nineteenth and twentieth centuries, as well as potential distributions in the future.

In his discussions of multipolar and bipolar worlds, the system operates according to the politics of Great Power primacy. The Multipolar, Tight Bipolar, and Loose Bipolar systems of Kaplan are Realist views of the international system. They recognize the anarchy and self-help aspect of the international system. Accordingly, the only players of note are the powerful nations, what Kaplan describes as his "essential actors" and "bloc leaders."

The Universal system that Kaplan describes, operates according to sovereign equality. In this system, a United Nations-like organization has evolved to a sufficient degree that it may impose formal rules upon the international 
system, ending its anarchic character. International law serves as a stronger force in this system. Such a system is the antithesis of Great Power primacy politics and would be highly favored by weaker nations. It works for the improvement of the poorer nations at the expense of the richer. ${ }^{62}$ This is the very platform advocated by the South in its efforts to achieve greater equity in the system. Kaplan's models of Great Power primacy and sovereign equality depict one of the recurrent tensions of the NorthSouth confrontation--the question as to who gets to make up the rules of the game.

This chapter has sought to depict how the concepts and notions of the 'other' hemispheric confrontation (East vs. West) fail to apply to the North-South encounter. Unlike the East-West dispute, North and South lack hegemons and the discipline they impose on blocs. East and west each perceived themselves to be striving for their security and ideological objectives; the struggle between the developed and developing worlds concerns the material objective. The Cold war pitted the strongest militaries and economies of the world against one another. The battle between North and South has the weakest nations challenging the strongest. This power differential dictates that the confrontation between North and South takes place at international organizations and conferences. It is made possible due to 
the twentieth century acceptance of the norm of sovereign equality. The next chapter will explore the development of this norm. 


\section{TABLE 1 \\ SUMMED RANKING OF COUNTRIES \\ AS OF 1964}

\section{RANK COUNTRY}

1 United States*

2 Soviet Union*

3 United Kingdom*

4 West Germany*

5 China

6 France*

7 Italy*

8 Canada*

9 India

10 Japan*

11 Poland*

12 Czechoslovakia*

13 East Germany*

14 Australia*

15 Sweden*

16 Netherlands*

17 Spain

18 Brazil

19 Belgium*

20 Yugoslavia

21 Argentina

22 Switzerland*

23 Turkey

24 Hungary*

25 Rumania*

26 Pakistan

27 Denmark*

28 Mexico

29 Bulgaria

30 Israel

31 United Arab Republic

32 Norway*

33 Iran

34 Austria*

35 Venezuela

36 Chile

37 Greece

38 North Korea

39 Indonesia

40 Finland*

41 Portugal

42 South Vietnam

43 Cuba

44 North Vietnam
GNP MILEXP GRP

$\begin{array}{rrl}1 & 1 & \text { NATO } \\ 2 & 2 & \text { WPACT } \\ 4 & 3 & \text { NATO } \\ 3 & 6 & \text { NATO } \\ 6 & 4 & \\ 5 & 5 & \text { NATO } \\ 8 & 7 & \text { NATO } \\ 9 & 8 & \text { NATO } \\ 10 & 9 & \text { G77 } \\ 7 & 12 & \\ 11 & 10 & \text { WPACT } \\ 14 & 11 & \text { WPACT } \\ 13 & 14 & \text { WPACT }\end{array}$

$12 \quad 16$

$17 \quad 13$

$18 \quad 15 \quad$ NATO

$16 \quad 17$

$\begin{array}{lll}21 & 18 & \text { G77 }\end{array}$

2019 NATO

$\begin{array}{lll}22 & 20 & \text { G77 }\end{array}$

$\begin{array}{lll}19 & 25 & \mathrm{G} 77\end{array}$

$23 \quad 26$

$29 \quad 21$

$26 \quad 24$ WPACT

$24 \quad 27$ WPACT

$\begin{array}{lll}25 & 31 & \text { G77 }\end{array}$

$27 \quad 33$

$\begin{array}{lll}15 & 46 & \text { G77 }\end{array}$

$33 \quad 34$ WPACT

$45 \quad 23$

$\begin{array}{lll}42 & 28 & 677\end{array}$

$32 \cdot 38$

$\begin{array}{lll}36 & 36 & \mathrm{G} 77\end{array}$

$28 \quad 45$

$\begin{array}{lll}30 & 44 & 677\end{array}$

$\begin{array}{lll}34 & 43 & \text { G77 }\end{array}$

$37 \quad 41$

$51 \quad 29$

$\begin{array}{lll}38 & 42 & \text { G77 }\end{array}$

$31 \quad 51$

$46 \quad 37$

$55 \quad 32$

$47 \quad 40$

$60 \quad 30$ 


\section{SUMMED RANKING OF COUNTRIES \\ AS OF 1964}

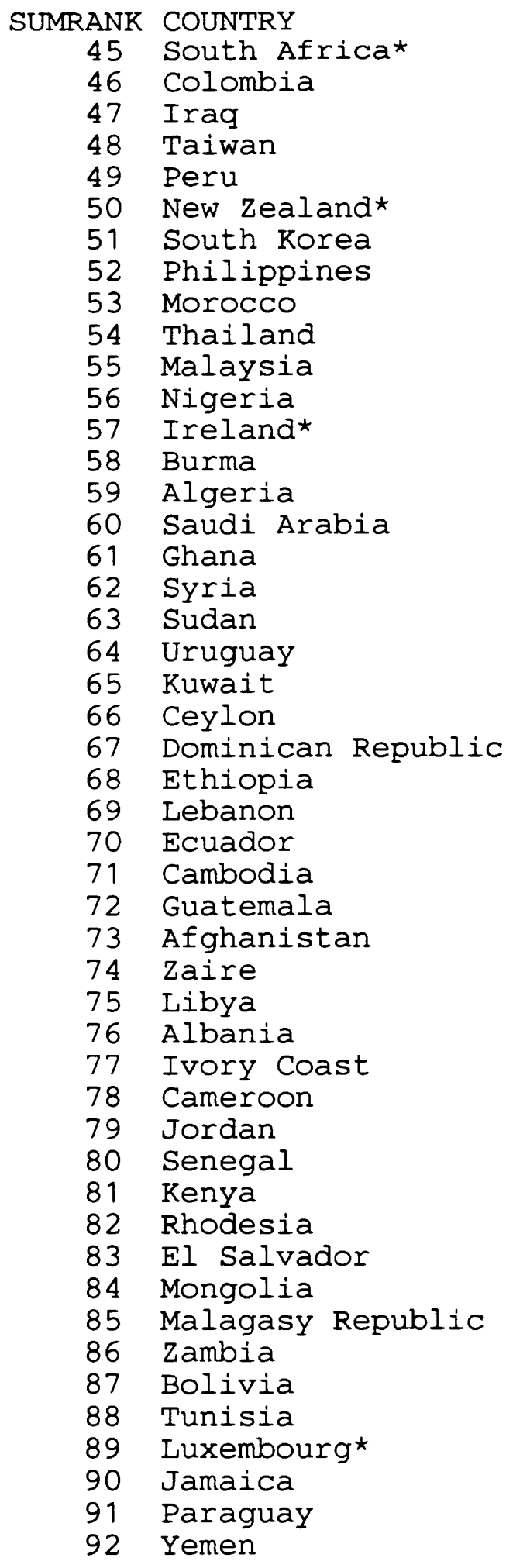

GNP MILEXP GRP

6922

$\begin{array}{lll}35 & 56 & \mathrm{G} 77\end{array}$

$\begin{array}{lll}57 & 35 & \mathrm{G} 77\end{array}$

$53 \quad 39$

$43 \quad 50 \quad 677$

$40 \quad 54$

$\begin{array}{lll}48 & 47 & \mathrm{G} 77\end{array}$

$39 \quad 58 \quad$ G77

$\begin{array}{lll}52 & 48 & \mathrm{G} 77\end{array}$

$44 \quad 57 \quad$ G77

$49 \quad 55 \quad G 77$

$\begin{array}{lll}41 & 63 & \mathrm{G} 77\end{array}$

$50 \quad 60$

$59 \quad 52 \quad G 77$

$\begin{array}{lll}54 & 59 & \mathrm{G} 77\end{array}$

$\begin{array}{lll}65 & 49 & \mathrm{G} 77\end{array}$

$56 \quad 65$

$\begin{array}{lll}77 & 53 & \mathrm{G} 77\end{array}$

$\begin{array}{lll}63 & 67 & \text { G77 }\end{array}$

$\begin{array}{lll}61 & 69 & \mathrm{G} 77\end{array}$

$\begin{array}{lll}62 & 72 & \mathrm{G} 77\end{array}$

$58 \quad 76$

$\begin{array}{lll}70 & 66 & \mathrm{G} 77\end{array}$

$\begin{array}{lll}66 & 70 & \text { G77 }\end{array}$

$\begin{array}{lll}71 & 68 & \mathrm{G} 77\end{array}$

$72 \cdot 71 \quad$ G77

$80 \quad 64$

$\begin{array}{lll}64 & 81 & 677\end{array}$

$\begin{array}{lll}68 & 78 & \text { G77 }\end{array}$

$\begin{array}{lll}67 & 79 & \text { G77 }\end{array}$

$\begin{array}{lll}76 & 73 & \text { G77 }\end{array}$

$88 \quad 62$

$75 \quad 82$

$\begin{array}{lll}84 & 74 & \mathrm{G} 77\end{array}$

$\begin{array}{lll}98 & 61 & \text { G77 }\end{array}$

$81 \quad 83 \quad$ G77

$\begin{array}{lll}73 & 91 & \text { G77 }\end{array}$

$74 \quad 92$

$\begin{array}{lll}82 & 86 & \mathrm{G} 77\end{array}$

$93 \quad 77$

$\begin{array}{lll}85 & 87 & 677\end{array}$

$86 \quad 88$

$95 \quad 80 \quad 677$

$\begin{array}{lll}79 & 96 & \text { G77 }\end{array}$

$89 \quad 89$

$\begin{array}{lll}78 & 104 & \mathrm{G} 77\end{array}$

$\begin{array}{lll}99 & 84 & \text { G77 }\end{array}$

$101 \quad 85 \quad$ G77 
SUMMED RANKING OF COUNTRIES

AS OF 1964

\begin{tabular}{|c|c|c|c|c|}
\hline MRANK & COUNTRY & GNP & MILEXP & \\
\hline 93 & Nepal & 87 & 99 & G7" \\
\hline 94 & Laos & 112 & 75 & G7 \\
\hline 95 & Uganda & 91 & 97 & G7 \\
\hline 96 & Nicaragua & 96 & 93 & \\
\hline 97 & Tanzania & 83 & 106 & \\
\hline 98 & Honduras & 97 & 98 & G7 \\
\hline 99 & Cyprus & 102 & 94 & G7 \\
\hline 100 & Mali & 107 & 90 & G7 \\
\hline 101 & Trinidad and Tobago & 90 & 107 & G7 \\
\hline 102 & Haiti & 104 & 95 & G7 \\
\hline 103 & Costa Rica & 94 & 110 & G7 \\
\hline 104 & Niger & 105 & 100 & G7 \\
\hline 5 & Guinea & 108 & 01 & G7 \\
\hline 10 & Panama & $b$ & 117 & G7 \\
\hline 107 & Upper Volta & 106 & 108 & G7 \\
\hline 108 & Sierra Leone & 103 & 111 & G7 \\
\hline 109 & Dahomey & 11 & 105 & \\
\hline 110 & Somalia & & 102 & G7 \\
\hline 111 & Iceland* & 100 & 118 & \\
\hline 112 & Congo, Democratic Rep & 117 & 103 & \\
\hline 113 & Chad & 109 & 112 & G7 \\
\hline 114 & Togo & 115 & 109 & G7 \\
\hline 1 & Liberia & & a & G7 ${ }^{\circ}$ \\
\hline 116 & Central African Rep & 1 & 4 & G7 \\
\hline 117 & Mauritania & 11 & 115 & G7 \\
\hline 118 & Gabon & 118 & 116 & G7 \\
\hline
\end{tabular}

* Indicates developed country according to ACDA

All data except bloc membership taken from, U.S. Arms Control and Disarmament Agency, World Military Expenditure Time Series, 1961-1970, Computer file, (Ann Arbor, MI: Inter-University Consortium for Political and Social Research, distributor, 197?[sic]).

Group of 77 membership data from Karl P. Sauvant, The Group of 77: Evolution, Structure, Organization, (New York: Oceana Publications, 1981), 103.

NATO and Warsaw Pact membership from Jeffrey Simon, ed., NATO-Warsaw Pact Force Mobilization, (Wash. D.C.: National Defense University Press: 1988), 33. 
NOTES

1. Stephen Krasner, Structural Conflict, (Berkeley: University of California Press, 1985), 267.

2. The terms Third world and South are used synonymously throughout this paper to describe the coordinated international political activity among developing nations.

3. The phrase "Cold War", coined by walter Lippman, referred to the division of the world into two opposing blocs, each with a superpower at its center. As cited in R. Harrison Wagner, "What was bipolarity," International Organizations 47, (Winter 1993): 80 .

4. The NIEO resolutions:

G.A. Res 3201 (S-VI),6(Special)U.N. GAOR Supp. (No.1) at 3, U.N.DOC.A/9556(1974).

G.A. Res 3202 (S-VI),6(Special)U.N. GAOR Supp. (No.1) at 5, U.N.DOC.A/9556 (1974).

G.A. Res 3281 (XXIX), 29U.N. GAOR Supp. (No.31) at 50,

U.N.DOC.A/9361(1974).

5. Marc Williams, Third World Cooperation: The Group of 77 in UNCTAD, (London: Pinter Publishers, 1991), 3.

6. Branislav Gosovic, UNCTAD Conflict and Compromise, (Leiden: A.W. Sijthoff, 1972), 4 .

7. Kenneth Waltz, Theory of International Politics, (New York: McGraw-Hill, 1979), 200.

8. Waltz, 88 .

9. Waltz, 111 .

10. Robert 0 . Keohane and Joseph S. Nye, Power and Interdependence 2nd ed., (Boston: Little, Brown, 1989), 151 .

11. Richard Rosecrance, International Relations: Peace or War, (New York: McGraw-Hill, 1973), 208-209.

12. In describing the psychology of individuals, A.H. Maslow created just such a hierarchy of needs. While his theory applied to individuals and not states, if one posits that states behave as rational actors, the theory applies here too. Maslow's notion described the most basic needs as lower order. "The higher the need the less imperative 
it is for sheer survival . . higher needs have less ability to dominate." A.H. Maslow, Motivation and

Personality, (New York: Harper \& Brothers, 1954), 146-150.

13. Keohane and Nye, 151. Arthur A. Stein, Why Nations Cooperate, (Ithaca: Cornell University Press,1990), 207. East, 157. Jeffrey Hart, "Three approaches to the measurement of power in international relations," International Relations 30, (Spring 1976): 305.

14. Robert O. Keohane, "Realism, Neorealism and the Study of World Politics," in Neorealism and Its Critics, (New. York: Columbia University Press, 1986), 11.

15. John Spanier, Games Nations Play, (New York:Praeger Publishers, 1973), 107.

16. Spanier, 104-105, 188-189.

17. Marshall R. Singer, Weak States in a World of Powers, (New York: The Free Press, 1972), 54.

18. Waltz, 192 .

19. This is not a reference to James $N$. Rosenau, Turbulence in World Politics, (Princeton, NJ: Princeton University Press, 1990).

20. Bruce M. Russett, "Components of an operational theory of international alliance formation," Journal of Conflict Resolution 12, (September 1968): 292.

21. David Garnham, "Power Parity and Lethal International Violence," Journal of Conflict Resolution 20, (September 1976) : 383. Russett, 293. Charles L. Taylor and Michael C. Hudson, World Handbook of Political and Social Indicators 2nd ed., (New Haven: Yale University Press, 1972).

22. Hart, 289. Hart cites studies by J. David Singer/Melvin Small and George Modelski.

23. Hart, 290.

24. Michael D. Ward, Lewis L. House, "A Theory of the Behavioral Power of Nations," Journal of Conflict Resolution 32, (March 1988), 15.

25. Michael P. Sullivan, Power in Contemporary International Politics, (Columbia, S.C.: University of South Carolina Press, 1990): 109. 
26. Hans J. Morgenthau, Kenneth W. Thompson, Politics Among Nations 6th ed., (New York: Alfred A. Knopf, 1985), 172.

27. Waltz, 94 .

28. William Thompson and David Rapkin, "Bipolarity and Bipolarization", Journal of Conflict Resolution 23, (June 1979): 269.

29. George Modelski, World Power Concentrations,

(Morristown: General Learning Press, 1974), 6.

30. Modelski, 6 .

31. Russett, 293.

32. Norton Ginsburg, Atlas of Economic Development,

(Chicago: University of Chicago Press, 1961), as cited in Russett, 293. Theodore Caplow and Kurt Finsterbusch, "A Matrix for Modernization," presented at the annual meeting of the American Sociological Association, 1964, as cited in Russett, 293.

33. Charles Lewis Taylor and Michael C. Hudson, World Handbook of Political and Social Indicators $2 d$ ed. (New Haven: Yale University Press, 1972).

34. The ' $*$ ' next to country name indicate a developed nation according to the ACDA. According to U.S. Arms Control and Disarmament Agency study.

35. The Group of 77 has been chosen to identify Third World nations because it is the only major Third World organization devoted exclusively to the members' economic problems.

36. Data except for G77 membership taken from, U.S. Arms Control and Disarmament Agency, World Military Expenditure Time Series, 1961-1970, Computer file, (Ann Arbor, MI: Inter-University Consortium for Political and Social Research, distributor, 197?[sic]). Countries for which data was incomplete have been excluded. Developing nations based on G77 membership. Developed nations based on ACDA designation.

37. Thompson and Rapkin, 282.

38. Morton Kaplan, System and Process in International Politics, (New York: John Wiley \& Sons, 1957), 22-28. 
39. Kaplan, 22 .

40. Dale P.Dean Jr., John A. Vasquez, "From Power Politics to Issue Politics," Western Political Quarterly 24, (March 1976): 8 .

41. Kaplan, preface xiv.

42. Rothstein, 242 .

43. Kaplan, 22-28.

44. Richard Rosecrance, "American Influence in World Politics," in Richard Rosecrance (ed.), America as an ordinary Country, (Ithaca: Cornell University Press, 1976), 226 .

45. Wagner, 82 .

46. Geir Lundestad, Major Developments in International Politics, (Oslo: Norwegian University Press, 1986), 237238 .

47. Kennedy: 379 .

48. Wagner, 81 .

49. Rothstein, 249.

50. Explored in Chapter 3.

51. Gilpin, 300 .

52. Williams, Third World Cooperation, 8.

53. Rapkin and Thompson, 283.

54. Waltz, 130 .

55. Waltz, 130, Kaplan, 36.

56. Thompson and Rapkin, 267.

57. Thompson and Rapkin, 267.

58. Thompson and Rapkin, 267-268.

59. China made a bid to become the leader of the Third World in the late 1950s. "But as the 1950s drew to a close, China had become more aggressive in its actions and rigid in its political philosophies, alienating many of 
its former Third World friends." Lillian Craig Harris and Robert L. Worden, China and the Third World: Champion or Challenger, (Dover: Auburn House Publishing, 1986), 2 .

60. During the early years of the Third World, a number of developing nations pursued a strategy of autonomous development or import-substitution. They sought to reduce foreign trade and meet their needs with domestic supplies. However, this strategy was adopted at the national level not the bloc level. For a number of reasons, it was never very successful. (Gilpin, 219-292.)

61. Kaplan, all.

62. Kaplan, 45-48. 


\section{THE EVOLUTION OF THE CONCEPT \\ OF SOVEREIGN EQUALITY}

The history of international relations is the history of the inequality of nations. As far back as the Peloponnesian War, power not morals, governed the relations between states. ${ }^{1}$ The previous chapter argued that the confrontation between North and South was the clash of unequals. Because of their weakness, the developing countries could not pursue their goals through military or economic means. However, the existence of international organizations based on the concept of sovereign equality offered a new type of power to weak nations. This chapter will investigate the theoretical underpinnings of the idea and the degree to which it has been accepted in international organizations.

Sovereign equality, also known as equality among nations may mean two things: equality before the law, and equality of participation and responsibilities. Equality before the law implies that all nations are treated equally by the law. Equality of participation and responsibilities suggests that all nations, weak and strong alike, should have an equal voice in establishing the law and sharing its benefits and burdens. The idea that all subjects of the law are entitled to its equal protection, is a prerequisite for any system of law. But equality before the law in no way implies equality of participation. ${ }^{2}$ While equality before the law has become a 
norm in international law, the call for equality of participation stirs hot debate and goes to the heart of the North-South dispute.

The idea of equality among nations is derived and yet distinct from the idea of sovereignty. Sovereignty is the defining characteristic of statehood. It has been described as consisting of three main elements: "First, the sovereign state is a full subject of international law; second, it is not under the control of any other state; and third, it is in fact able and free to exercise a fair amount of state power." 3

As a result of the basic condition of sovereignty, states become members of the international community and subjects of international law. In contrast to sovereignty, sovereign equality involves the degree to which sovereign nations are treated equally as members of the international community.

\section{Background of the Theory}

Given the tremendous differences that exist between nations (population, land area, wealth, military, etc.), the idea of their equality is not intuitively obvious. Given this, how could such a notion have developed? The theory of equality among states is predicated upon the idea of equality among men. This latter notion, based in natural law, has existed since antiquity. ${ }^{4}$

Thomas Hobbes built upon the idea that man's rights arise as a result of his condition in the state of nature. ${ }^{5}$ His contribution to the development of sovereign equality is the 
notion that the state itself is an individual and entitled to certain rights.

For by art is created that great LEVIATHAN called a COMMONWEALTH Or STATE - in Latin, CIVITAS - which is but an artificial man, though of greater stature and strength than the natural, for whose protection and defense it was intended, and in which the sovereignty is an artificial soul, as giving life and motion to the whole body . . . ${ }^{6}$

Hobbes conceived of the state as a corporate entity entitled to rights and granted authority. ${ }^{7}$ of course, the idea of the state as an individual seemed particularly relevant at a time when sovereign princes truly personified the state.

Samuel Pufendorf took the next step in the development of sovereign equality. He accepted the idea of the equality of men arising out of the state of nature ${ }^{8}$. He also enlarged upon Hobbes' conception of the state as an individual, describing the state as a "compound, moral person."9

Iikening the anarchic character of international relations to man's existence in the state of nature, Pufendorf built the case for the equality of states. Both international relations and the state of nature are environments that lack any higher authority to impose order upon anarchy. Pufendorf concluded that a state's relationship to other states is the same as man's relationship to other men in the state of nature. ${ }^{10}$ Since the equality of man arises out of his condition in the state of nature, so too, the equality of states arises from the anarchy of international relations.

In a famous quotation, Emeric Vattel succinctly states 
the doctrine of the equality of states:

Since men are by nature equal, and their individual rights and obligations the same, as coming equally from nature, Nations, which are composed of men and may be regarded as so many free persons living together in a state of nature, ${ }^{11}$ are by nature equal and hold from nature the same obligations and the same rights. Strength or weakness, in this case, count for nothing. A dwarf is as much a man as a giant is; a small Republic is no less a sovereign state than the most powerful Kingdom. 12

The work of writers such as Hobbes, Pufendorf, and Vattel laid the theoretical foundation for the concept of the equality of states. This concept would gain greater importance as the forces of the twentieth century brought nations into increasing contact with one another.

Theory of

International Organizations

Due to the growing interaction between nations, there arose a need for a more effective way to regulate international relations. This need for a more permanent body for negotiation and administration resulted in the creation of international organizations. In studying these organizations, it is useful to understand how they differ in their functional orientation, and how this orientation affects their methods of decision-making.

Stephen zamora distinguishes between three functional roles for international organizations: recommendatory agencies (e.g., the General Assembly), specific subject-oriented agencies (e.g., the IMF), and administrative task-oriented 
agencies (e.g.. International Atomic Energy Agency). ${ }^{13}$ This chapter is concerned with only the first type, the recommendatory agencies.

Broad

High

Advisory

Recommendatory
PURPOSE

POLITICS

POWER

ORGANIZATION TYPE
Narrow

Low

Binding

Admin.

If one pictures a continuum based on the breadth of an organization's purpose, one finds that broad purpose, high politics agencies, such as the United Nations General Assembly, enjoy only advisory power. At the other extreme, low politics agencies with a limited, defined purpose, such as the International Civil Aviation Organization, may issue binding decisions. ${ }^{14}$

The ability of administrative international organizations to issue binding decisions runs contrary to a longstanding rule of international law--the principle of consent. According to this principle, a state cannot be bound by a decision of a majority of its fellows, no matter how big the majority, unless it has given specific consent to such a procedure. This precept serves as one of the primary distinctions between domestic and international law. ${ }^{15}$ Because the decisions of administrative agencies tend to be narrow and technical, the benefits of these actions are seen to outweigh the minor infringement upon states' sovereignty. ${ }^{16}$ 
Decision-making procedures of international organizations are commonly classified into three categories: equalitarian, majoritarian, and elitist. ${ }^{17}$ Equalitarianism represents the fusion of the concepts of sovereign equality and consent. Equalitarianism, also known as unanimity, implies that every nation has an equal vote and that no decision may be made without the consent of all nations present. Although unanimity represents the least infringement upon sovereignty, it seriously hampers organizational decision-making. Majoritarianism, also based on the one-nation, one vote principle, is modeled after domestic voting. Under this procedure, a majority vote is sufficient to reach a decision. Elitism, or weighted voting, runs contrary to the idea of sovereign equality. In this case, the votes of certain nations receive more weight than others. Powerful nations often prefer this method because it may more closely approximate the effect of power on international politics. Feld and Jordan discuss the variation in voting methods:

In summarizing our discussion of voting systems, it appears that the more technical or perhaps low politics the issue areas in which an IGO is concerned, the greater the chances that simple majorities are employed for the approval of decisions. Conversely, the more high politics are involved in particular decision making with IGOs, the greater is the tendency to insist on unanimity in voting. In this way, it is not likely that perceived vital interests of member-states may be adversely affected. ${ }^{18}$ 
The History of

International Organizations

In the realm of high politics, the norm of sovereignty has often necessitated that either binding decisions be unanimous or majoritarian decisions be recommendatory. The method for making decisions, and the legitimacy of the decisions themselves have undergone an evolutionary process that can be traced back to the Congress of Vienna. As demonstrated by this case, the norm of sovereign equality was even less accepted at that time than it is today. Shortly after vattel wrote that "the dwarf is as much a man as the giant,"19 the giants demonstrated the difference that size can make.

Subsequent to their victory over Napoleon, the powerful nations of Europe issued a call to strong and weak alike to attend the Congress of Vienna in order to decide the fate of continent. Although the call for such a conference nominally adhered to the notion of equality, in truth, "After the defeat of Napoleon, in the spring of 1814, the principal allied powers assumed the task of restoring the peace and order in Europe. At the Congress of Vienna, the four most powerful states - . assumed the responsibility for European security."20 During the proceedings of the Congress, and of subsequent international organizations, a tension has existed concerning decision-making. Based on the principle of sovereign equality, weaker states have claimed an equal right 
in the decision process. Stronger states, on the contrary, prefer that those responsible for implementing a decision have the greatest say in making it. Decisions based on sovereign equality tend to carry greater moral authority, yet decisions made contrary to the wishes of the Great Powers, ${ }^{21}$ are unlikely to be implemented.

Just as they had after the Napoleonic Wars, the victorious nations of World War I, called for an international conference to prevent the recurrence of cataclysmic war. Unlike the Congress, the League of Nations was to be a permanent body. Although the leaders of the Great Powers, including Wilson, had originally envisaged an organization based on Great Power primacy, 22 the resultant organization represented a compromise between Great Power primacy and sovereign equality. The League was to be composed of three organs: the Secretariat, the Council (embodying Great Power primacy) and the Assembly (embodying sovereign equality). ${ }^{23}$ In deference to their position, the Great Powers received five permanent seats on the Council of the League.

In accordance with the concepts of sovereign equality and consent, every nation had one vote. The decisions of the League would be based on the principle of unanimity. ${ }^{24}$ Given the ability of the League to invoke collective security measures against a state ${ }^{25}$, one might at first question the willingness of the Great Powers to accept such a threat to their sovereignty. 
However, the unanimity rule negates the formal power of sanctions. The Great Powers agreed to join the League because they could thwart its actions. "It is noteworthy that the League institutions have little power. . . In so far as League institutions are equipped to ensure permanent peace, their most important powers, with a few exceptions, are of an advisory or ministerial character."26 while safeguarding the sovereignty of its member nations, the League's adoption of the unanimity rule hampered its ability to keep peace.

The outbreak of a second world war in less than thirty years demonstrated the ineffectuality of the League. Even before the end of World War II, the allies met to discuss plans for a new international organization to take the place of the League. As they had after the last two major wars, the allies hoped to create an organization that would spare the world another global hostility. The absence of the United States (and later, other Great Powers) is commonly seen as a fundamental flaw of the League. The founders of the United Nations believed that Great Power participation was fundamental to the organization's success, and structured it accordingly. ${ }^{27}$

Although the Covenant of the League set a precedent by accepting sovereign equality and unanimity, the failure of the League demonstrated the need for changes. Political realities, both international and domestic, required that the United Nations embody a compromise between sovereign equality 
and Great Power primacy. However, in comparison with the League, the Charter strengthened the hand of the Great Powers and made fewer concessions to sovereign equality. Like its predecessor the League of Nations, the two principal political bodies of the United Nations are a Council and an Assembly. The Security Council, again the bastion of Great Power primacy, holds permanent seats for the Great Powers. The General Assembly, again the embodiment of sovereign equality, has only hortatory powers.

The voting in the United Nations differs in two important aspects from that of the League. Voting in the League, in both the Assembly and the Council, was based on unanimity. In the United Nations, voting in the Assembly is based on majoritarianism, while voting in the Security Council is a combination of majoritarianism and unanimity. In the security Council, nonprocedural matters must gain both a majority of all members and the unanimous consent of all permanent members. The founders of the U.N. made this concession to Great Power primacy to ensure the participation of the powerful states. All but the Great Powers surrendered a degree of sovereignty by agreeing to accept the "majority" decisions of the Security Council. The Great Powers became the only members able to stymie the will of the security Council. ${ }^{28}$

While the change from equalitarian to majoritarian voting was intended to increase the effectiveness of the 
organization, the new design enjoyed questionable success during the forty odd years of the cold war. The requirement for unanimity among the Great Powers, predicated the success of the United Nations upon cooperation among them.

The unity of the great powers is the core of the peacekeeping plan. The framers reasoned that as long as the great powers remained united in their desire to maintain peace and security . . . no other power or group of powers could stand against them. The council's role was regarded by its architects as both natural and realistic, since World War II had reaffirmed the premise that war-making, and hence peacekeeping, is largely a great power choice. ${ }^{29}$

The outbreak of the Cold war quickly dashed the hopes for Great Power consensus. ${ }^{30}$ Just as the unanimity rule and the lack of consensus had paralyzed the League, so too, the Great Power unanimity rule and the absence of Great Power agreement, prevented the United Nations from fully realizing the dreams of its founders.

\section{Summary}

The change from unanimous to majoritarian voting had limited success in alleviating the paralysis that had plagued the League. But the chronic weakness of high politics international organizations is less a function of internal procedures than of the nature of international politics. The notion of an international authority is antithetical to sovereignty, upon which the nation-state system is based.

The tension between Great Power primacy and sovereign equality reflects the struggle for power in the international 
system. Those nations unable to assert themselves militarily or economically, seek power in the concept of equality among nations. The debate hinges on the question of whether this should simply be equality before the law or equality of participation.

If today we are to find in the United Nations the principal institutional expression of the demand for greater equality, we must do so in terms of what the organization has become and not in terms of what it was initially intended to be. The change from an instrument of the great powers to a forum in which the new states could press their claims begins in the late 1950s and coincides with events that suddenly gave the weak of the world unexpected significance. ${ }^{31}$

One of these events would be the emergence of the Third world. 
NOTES

1. Thucydides, The History of the Peloponnesian War, (London: J.M. Dent \& Sons, Ltd, 1974), 300-306.

2. Edwin Dewitt Dickinson, The Equality of States in International Law, (Cambridge: Harvard University Press, 1920), 3-5.

3. Lapidoth produced this definition after having surveyed the opinions of numerous legal scholars. Ruth Lapidoth, "Sovereignty in Transition," Journal of International Affairs 45 (Winter 1992): 325-346.

4. Dickinson, 13-17.

5. Thomas Hobbes, Leviathan, (Indianapolis: Bobbs-Merrill Co., 1958), Ch. 13-14.

6. Hobbes, 23.

7. Pieter Hendrik Kooijmans, The Doctrine of the Legal Equality of States, (Leiden: A.W. Sijthoff, 1964), 72-73.

8. Samuel Pufendorf, "De Jure Naturae Et Gentium Libri Octo," in James Brown Scott, ed., Classics of International Law, vol. II, translation of edition of 1688 by C.H. and W.A. Oldfather, (New York: Oceana Publications, repr. in 1964), II, 2, 3 .

9. Pufendorf, VII, 2,13.

10. Pufendorf, II, 2, 4 .

11. In speaking of nations as "persons" and "men," Vattel acknowledged a shift in the nature of sovereignty. Rather than residing in monarchs, sovereignty exists in the people of a nation.

12. Emeric de Vattel, Le droit des gens ou principes de la loi naturelle appliques a la conduite et aux affaires des nations et des souvervains, New ed. by Joseph Chitty, Esq, (Philadelphia: T \& J Johnson, 1870), 59, Sect. 18.

13. Stephen Zamora, "Voting in International Economic Organizations," American Journal of International Law 73 (July, 1980): 569 
14. Zamora, 569.

15. Alan James, "The equality of states: contemporary manifestations of an ancient doctrine," Review of International Studies 18 (October 1992): 382. zamora, 571.

16. Zamora, 575.

17. Inis L. Claude, Swords Into Plowshares. (New York: Random House, 1964), 126. Zamora, 571.

18. Werner Feld and Robert Jordan, "Patterns of Decisionmaking in International Organizations," in Paul F. Diehl, The Politics of International Organizations, (Chicago: Dorsey Press, 1989), 126.

19. Vattel, 59, sect. 18 .

20. Klein, 10 .

21. The term "Great Power" was first used as a diplomatic expression in the Treaty of Chaumont in 1814. Klein, 12.

22. Klein, 69-72.

23. Klein, 74 .

24. Covenant of the League of Nations, Article 5.

25. Covenant of the League of Nations, Article 16.

26. Dickinson, 371-374.

27. J. Martin Rochester, waiting for the Millennium, Columbia, S.C.: University of South Carolina Press, 1993), 114 .

28. Zamora, 573.

29. Robert E. Riggs and Jack C. Plano, The United Nations, (Pacific Grove, CA: Brooks/Cole Publishing Company, 1988), 38 .

30. Except for the period in which the United for Peace Resolution was in effect. During this period, deadlocks in the Security Council were referred to the General Assembly in which the United States enjoyed a majority.

31. Robert $W$. Tucker, The Inequality of Nations, (New York: Basic Books, Inc, 1977), 34 . 


\section{CHAPTER III \\ THE EMERGENCE OF THE SOUTH}

\section{Postwar Changes}

The emergence of the Third world after the end of world War II can be traced to changes in three areas: the international power balance, the monetary/trading regimes, and the colonial empires of the Great Powers. These changes would result in the creation of a large number of weak states, and these states would feel that the international political and economic systems worked against their interests. Militarily and economically weak, these states found a sense of common identity in their rejection of superpower politics and their call for reforms of the international economic system. Eventually these small, weak states would challenge the international economic regime of the strong, and foment the North-South conflict.

The first change in the system, the transformation of the international power balance, reduced the number of Great Powers to two, now termed superpowers. Except for the United States and the Soviet Union, the war had seriously weakened the powerful nations of the world. Prior to the conflict, the international system had been characterized by a "balance of power," shifting alliances, and the existence of Great Powers. After the war these features were replaced by bipolarity, military/economic blocs, and superpowers. The war had established the United States as the premier economic power of the world.1 This transformation of the international power 
structure would be reflected in the second area of change the international economic regimes.

Events leading up to the war and the war itself, had damaged the international monetary and trading regimes. Hegemonic Stability Theory asserts that international cooperation is most easily created and maintained in the presence of a hegemon. ${ }^{2}$ Britain had served in this role until the decline of British power in the 1930s. In the absence of a hegemon, the world economic system degenerated into economic warfare. Domestic concerns and nationalistic tendencies triumphed over international cooperation. ${ }^{3}$

From its postwar position of "unchallenged hegemonic leadership,"4 the United States asserted its power to establish new regimes in the areas of money and trade. The United States, and to a lesser extent, Great Britain, took the lead in formulating a liberal economic order at Bretton woods in 1943. This eventually resulted in the creation of the International Bank for Reconstruction and Development (the World Bank) and the International Monetary Fund. 5 The IMF, the World Bank, (and later GATT,) were oriented around the problems of the industrialized nations. ${ }^{6}$

"The Bretton woods institutions had never been joined by the third great international economic agency envisaged in the planning for the postwar period--the International Trade Organization (ITO)."7 This third organization, the ITO, would have had a greater orientation toward the concerns of the 
developing countries. When the industrialized countries rejected the plan for the ITO, the General Agreement on Tariffs and Trade arose in its place. "The underlying principle of GATT--reciprocity and bargaining in a quid pro quo situation--made its actions dependent on the big trading nations. For this reason GATT produced results that were either injurious or not beneficial to the developing countries."8 This inattention to the needs of developing nations would eventually lead to Third World calls for reforms.

The third area of major change following the war, was the end of the European colonial empires. Robert Jackson writes that, decolonization

- . stemmed from a rather sudden and widespread change of mind and mood about the international legitimacy of colonialism which aimed at and resulted in its abolition as an international institution. During and after World War II, colonialism became controversial and finally unacceptable in principle. ${ }^{9}$

However, in ending the "evil" of colonialism, the European powers created another problem. The new nations, termed "quasi-states"10 by Jackson, lacked the state authority, effective governmental organizations, and political community that characterized modern states.

Because of their history as colonial states, most Third World nations suffer from military, economic, and political weakness. Set within an anarchic, international system, these 
weak states suffer a chronic disadvantage.

Third World states, like all states in the international system, are concerned about vulnerability and threat . . - national political regimes in almost all Third World countries are profoundly weak both internationally and domestically. . . . This weakness stems from the inability to influence unilaterally or to adjust internally to the pressures of the global markets. . . Small size and inflexible domestic structures make Third World states vulnerable."

One of the tasks of government is to buffer domestic affairs from the effects of a volatile international economic system. But this task is made more difficult in the case of a weak state. A weak, nonindustrial state is at great disadvantage in the international system. Large industrial states set the terms of the international economic system. Small industrial states while having little say internationally, can still adjust their domestic economies to the changing international scene. However, small nonindustrial nations have no say in the international system and cannot make internal adjustments to minimize the impact of changes. ${ }^{12}$

\section{Nonalignment}

The end of the colonial empires resulted in the creation of small, chronically weak states. These small nonindustrial states found their interests largely ignored in the battle between the two superpowers. The Third World's economic problems seemed of little import to a world preoccupied by the superpower's threats of mutual destruction. Because East and 
West largely ignored the plight of the developing countries, the Third world nations lacked a vested interest in the cold War. Whether they joined one of the blocs or remained individual states outside of them, their weakness translated into a lack of influence. A third choice for the developing nations was the formation of $a$ new and independent bloc. Rothstein sees the Third World as "repudiating the traditional system of international politics - a system which excluded, ignored, or abused them. . . "13 Their choice was for neither East nor West but nonaligned. Thus at its inception, the Non-Aligned Movement (NAM) was defined not in terms of the North-South conflict but the East-West one. ${ }^{14}$

Given the vast disparity of interests among developing nations, the formation of a Third World bloc was a difficult task. By defining itself in terms of its opposition rather than its commonality, it overcame the problem of its diversity.

Although commonly referred to as the Third world, this group of nations is actually composed of two independent organizations, the NAM and the Group of $77^{15}$. At a conference in 1961, the developing nations formed the Non-Aligned Movement (NAM). They sought to create a third political force, independent of either superpower. The Movement's members hoped that by forming a coalition, their agenda would be given more weight in international politics. During its first ten years, the issues of decolonization and East-West 
tensions dominated the Movement. ${ }^{16}$ Although the NAM failed to have much impact on the politics of the East-West struggle, the organization shifted its focus toward economic problems as development issues gained importance. ${ }^{17}$

The policy of nonalignment differs from what is commonly seen as a policy of neutrality. James Caporaso defines the concepts:

Neutrality is the legal term referring to the status, rights, and responsibilities of states during armed hostilities. Nonalignment, on the other hand, is a term denoting a particular pattern of behavior or a policy posture adopted by a state. Holsti sees the essence of this policy as a refusal on the part of states "to commit themselves militarily to the goals and objectives of the major powers." 18

Neutrality implies a decision to withdraw from an arena of hostile political activity. In contrast, nonalignment, implies a deliberate decision to avoid choosing sides yet not necessarily a withdrawal from action.

\section{Underdevelopment}

Although much of the developing world realized political independence in this period, economic independence continued to elude them. The problem of underdevelopment seemed to be chronic. Three main schools of thought seek to explain the ongoing problem of underdevelopment: economic liberalism, the structuralist position, and the Marxist-radical position. ${ }^{19}$

Liberal economists believe that international trade promotes development. They assert that the division of the world into developed and developing nations will gradually 
disappear as the latter become industrialized. Liberals believe that the problem lies in barriers to free trade that are erected by domestic political and social forces. The key to the problem lies in the lack of efficiency in domestic markets, not the forces of the international market. ${ }^{20}$

Structuralism attributes Third world poverty to the underlying structure of the international economic system. According to one of the early advocates, Gunnar Myrdal:

Market forces will tend cumulatively to accentuate international inequalities, [and] a quite normal result of unhampered trade between two countries, of which one is industrial and the other underdeveloped, is the initiation of a cumulative process toward the impoverishment and stagnation of the latter. ${ }^{21}$

Contrary to liberal assumptions that international trade alleviates underdevelopment, this argument claims that the structure of the international marketplace reinforces it. Rather than lessening the gap between rich and poor, international trade widens it. ${ }^{22}$ The structuralists advocated a policy of import substitution to end underdevelopment.

The 1960s saw the appearance of a more radical alternative to the structuralist argument, Dependency Theory. This argument agrees with structuralism that the international economic system worsens underdevelopment. However, Dependency Theory is heavily influenced by Marxism. It claims that the wealth of the North is directly responsible for the poverty of the South. The success of capitalism is based upon the exploitation of one group by another. ${ }^{23}$ Furthermore, the 
theory posits that ruling elites in developing countries have an interest in maintaining the inequalities of the capitalist system. ${ }^{24}$ Robert Gilpin writes:

. . the underdeveloped periphery is necessarily backward and underdeveloped because the periphery is systematically exploited and prevented from developing by international capitalism and its reactionary domestic allies in the Third World economies themselves. ${ }^{25}$

Prior to the Third World's adoption of an Underdevelopment position, poverty served as their only common bond. Structuralism and Dependency Theory identified the causes and offered solutions. They provided a common framework that helped build solidarity and unity. Stephen Krasner maintains that the adoption of a common ideology was key to overcoming their differences.

The development of a coherent set of ideas . . . has provided the basis not simply for unity among Third World states but for the very idea of the Third World itself. - . Domestic and international weaknesses made Southern unity an immanent tendency in the post-World war II global order; but the actualization of that unity was dependent on the development of a common world view. ${ }^{26}$

The structuralist argument and the unity it brought to the Third World would be demonstrated at the first United Nations Conference on Trade and Development (UNCTAD) in 1964.

\section{UNCTAD I}

The early 1960s witnessed a confluence of forces that furthered the global alignment into North and South. 
Developing nations believed that the existing trading regime, GATT, favored rich nations. The Third world sought a forum in which sovereignty, not wealth, was the basis for voting. ${ }^{27}$ An earlier attempt to create an international trade organization had failed due to rejection by the North. The American attitude toward the conference changed due to East-West pressures not North-South ones. A soviet attempt to woo the developing states led America to fear increased Soviet influence in the Third world and caused the U.S. to drop its objections to an international trade conference. ${ }^{28}$

A shift in the balance of power within the United Nations also precipitated the global alignment into North and South. The entry of 18 developing states provided the Third world with a majority in the General Assembly. ${ }^{29}$ If the developing nations could muster sufficient solidarity, they could control the voting there. The Third world displayed its unity on economic matters at a conference in Belgrade in 1961. At this meeting the NAM called for an international conference to discuss the economic problems of the developing world. ${ }^{30}$ The combination of the new superpower interest, the changed makeup of the General Assembly, and Third World solidarity resulted in United Nations General Assembly Resolution 1707 (XVI) - the call for an international trade conference.

Raul Prebisch, one of the leading advocates of Third World unity, served as secretary-General to UNCTAD I. An early proponent of structuralism, he sought to explain the 
Third World's underdevelopment in terms of the international economic system. Richard Gardner describes the impact of Prebisch's report:

Even more significant than behavior at the Conference was the impact of Raul Prebisch's brilliant report, "Towards a New Trade Policy for Development." Both in its diagnosis and its prescriptions this document gave new impetus to the principal demands of the less developed countries. - . One of the central concepts in the Prebisch report was that steadily deteriorating terms of trade constitute one of the principal obstacles to the development of the less developed countries. ${ }^{31}$

One of the most lasting effects of the conference involved the institutional question - the matter of a continuing international trade body. The developed nations preferred the existing $\mathrm{GATT}^{32}$ organization and sought to prevent the creation of any new institution. The developing nations desired a new body, under U.N. auspices, in which voting would be based on sovereign equality, and thus give them a greater voice. ${ }^{33}$

Western nations agreed to the demand for a new organization, but sought to avoid a situation like that of the General Assembly, in which the developing countries had control by virtue of their numbers. The industrialized nations first proposed that the permanent group (or standing committee) be composed equally of developed and developing nations, regardless of their ratio in the United Nations. The next offer by the industrialized nations insisted that decisions by the standing committee be approved by a majority 
of the twelve industrialized nations present. Eventually North and South reached a compromise in which the developed nations dropped their demand to block resolutions and the developing nations agreed to a conciliation procedure. ${ }^{34}$ This negotiation over voting procedures mirrors the ongoing tension in international politics between Great Power primacy and sovereign equality. Strong nations want voting procedures to reflect international power; weak nations prefer procedures to be based on full equality among nations.

National groupings have always played a major role in the United Nations and continued to do so at UNCTAD. "The official groupings established at the first UNCTAD meeting were basically regional--Afro-Asian, Latin American, advanced market economy, and socialist--not North-South."35 As nations jockeyed back and forth, proposing and revising resolutions, the conference began to resolve into North and South.

During this formulation of voting resolutions, the developing nations caucused informally and drew up their own joint resolution. This resolution, signed by the Group of $75^{36}$, signaled the unity of the developing nations on economic issues. The resolution itself highlights this fact.

The developing countries regard their own unity, the unity of the seventy-five, as the outstanding feature of this Conference. This unity has sprung out of the fact that facing the basic problems of development they have a common interest in a new policy for international trade and development. ${ }^{37}$

Although two independent Third World organizations existed, 
their agendas differed. Whereas the NAM focused on political issues during these years, the Group of 77 concentrated on economic ones. ${ }^{38}$

The solidarity displayed at UNCTAD I and subsequent conferences is somewhat surprising considering the vast differences among the membership of the G75. Another barrier to unity had been the strength of regional ties. The Latin American, African, Arab, and Asian states each had their own regional organizations. A true Third World economic conference didn't occur until 1962 when Latin American countries joined Asian and African for the first time. ${ }^{39}$

The challenge mounted by the Third world during UNCTAD I became the opening salvo in the conflict between the North and the South. The conference and the Group of 75 are important because they mark the beginning of a unified South advocating a comprehensive plan for the future.40

The Final Act and Report issued by the conference ${ }^{41}$ bore a close resemblance to the Joint Resolution of the Group of 75. Of course, given that group's majority and the voting procedures, the outcome was hardly unexpected. However, like the resolutions of its parent body, the General Assembly, the resolutions of the UNCTAD are of a symbolic not a binding nature. The industrialized nations preferred to accept the conclusions of the conference due to their limited effect. Without the active support of the North, Southern calls for reform would go unheeded. 
UNCTAD I also marked a fundamental change in the international alignment among nations.

Until the early 1960s. . developed Western countries were usually able to negotiate acceptable resolutions with "moderate" less developed countries. Although there were clearly identifiable interest groups on economic issues, negotiations and voting did not usually take place on the basis of rich-and poor-country blocs. With the advent of UNCTAD the pattern changed. ${ }^{4}$

UNCTAD I "was the first international conference at which the North-South divide appeared as a salient feature in world politics, obscuring and relegating the East-West conflict to a secondary position."43 The conference set the tone for the North-South discussions ever since.

\section{The North-South Divide}

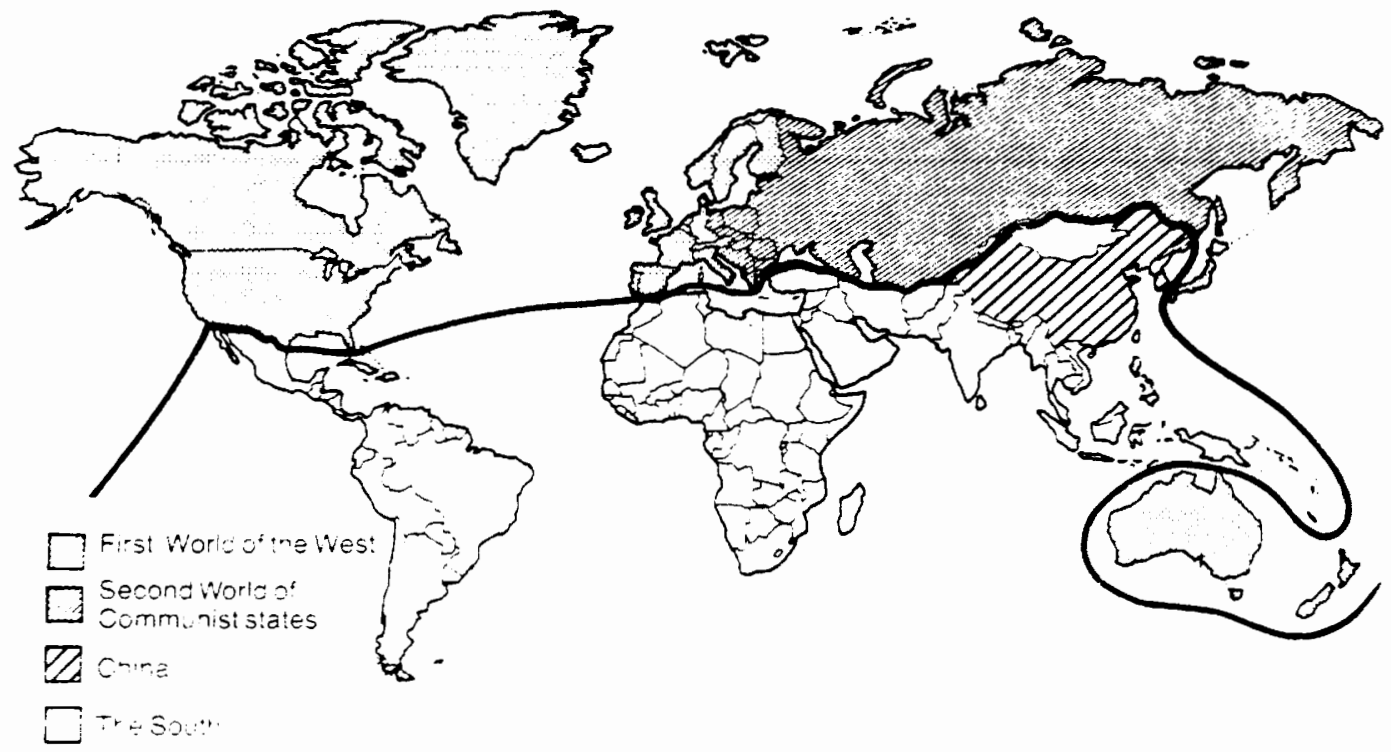

Guy Arnold, The Third World Handbook, London: Cassell Educ., 1989,42 . 
The New International Economic Order

The final report issued by UNCTAD I represented the first coherent, comprehensive economic program articulated by the developing countries. Encouraged by the success of the conference and, later, the OPEC cartel, the South aggressively sought reforms in the international economic system. By virtue of its majority in the U.N. General Assembly, the South would push through resolutions ${ }^{44}$ calling for the establishment of a New International Economic Order (NIEO).

Calls by the developing nations to modify the international economic system predate the formal passage of the NIEO. Ever since the first U.N. Conference on Trade and Development in 1964, the establishment of these reforms had been the primary objective of the Third World. ${ }^{45}$

Following the South's success in creating a permanent UNCTAD, developing countries viewed the formation of the OPEC cartel as another victory of the weak over the strong.

The dramatic and vastly profitably seizure of control over petroleum by oil-producing LDC nations pointed toward possible supply control and price boosts for other commodities produced by LDCs and more broadly suggested possibilities for new structures of organization and power for the Third World. ${ }^{46}$

OPEC's ability to determine the price of oil, encouraged other developing nations to challenge the North in a number of ways, including the proposal of the NIEO.

The New International Economic Order was not the result of any single conference or event. Rather it represented the 
gradual coalescence of a series of ideas into a coherent program. Support for this effort culminated in the passage of the NIEO resolutions by the United Nations General Assembly in 1974.47

These sweeping resolutions called for major changes in the international free market system for the benefit of developing nations. The resolutions sought to: stabilize international commodity markets, increase access to industrial nation's markets, adjust tariffs to advantage the South, strengthen the sovereignty of developing states and increase financial aid and technology transfers to the Third world. ${ }^{48}$ Because the World Bank and IMF operated under weighted voting rules that favored the developed countries, the Third world also called for changes to increase their representation in those bodies. ${ }^{49}$

The extent of the gap that existed between North and South is illustrated in Table 1 at the end of the chapter. The year 1979 was chosen because it falls midway between UNCTAD I and today. The thirty-four low-income countries have an average income of $\$ 150$, while the eighteen industrialized nations (the West) have a per capita GNP of $\$ 6980$. I. William Zartman writes that "The essence of the problem is that the two parts of the world are at different stages of development." 50 Although the South's U.N. majority succeeded in passing these resolutions, their implementation was another matter. The forum of the United Nations provided a pulpit 
from which the South could call for reforms, but neither the General Assembly nor the Third world had the wherewithal to change the international economic system--only the North could do that. But as far as the North was concerned, the liberal economic system worked quite well. The limited voice of developing countries on economic matters was considered to be commensurate with their role in international economics. 51 Because the reforms of the NIEO were never accepted by the developed nations, the NIEO has made little progress. ${ }^{52}$

The South sought to frame the argument for the NIEO along moral and humanitarian lines; it argued that the inequalities of the system are immoral and called for reforms to correct it. Yet some political scientists have questioned this moralsounding cry. Michael Sullivan writes that "despite much of the humanistic and moral tone taken by many of the Third World nations - . ultimately their real concern is with power, their current lack of power, and their desire to attain more power."53 He maintains that the North-South conflict should be analyzed in terms of Realpolitik rather than humanitarian issues.

Hans Morgenthau, one of the early twentieth century political realists, concurs with this view, stating that the causes of the disparity are much more than just the policies of the rich.

Thus the terms in which the so-called North-South conflict is fought out between the have and the have-not nations of the world in good measure conceal and at the 
same time justify a conflict between the traditionally powerful and the new politically weak nations whose main real object is exactly a new distribution of power. ${ }^{54}$

The South's repeated calls for an NIEO, whether motivated by humanitarian or realist reasons, have failed to achieve much change. The power of sovereign equality did enable the South to influence the international agenda, and at least enter into dialogue with the North. However, the North's willingness to negotiate (e.g. UNCTAD), is not the same as a willingness to change.

Joan Edelman Spero writes that: "Unity and confrontation are effective only if the South can withhold that which the North wants or needs. But the South has had very little with which to threaten the North."55 Due to the military and economic weakness of the South, it has been unable to threaten the North in any way. ${ }^{56}$ The lack of any credible threat has prevented the south achieving its goals in the international system. However, as global environmental issues gained importance by the 1970s, this situation changed. The degree to which the North has perceived certain international environmental problems as threats, the south has gained a limited amount of power. The following chapter will explore the nature and evolution of this power during the negotiations to reduce ozone depletion. 
Table 1: Basic Indicators

\begin{tabular}{|c|c|c|c|c|c|c|c|c|c|}
\hline & \multirow{3}{*}{$\begin{array}{l}\begin{array}{c}\text { Popula- } \\
\text { tion }\end{array} \\
\cdot \\
\frac{\text { (millions) }}{\text { Mid-1977 }}\end{array}$} & \multirow{3}{*}{$\begin{array}{c}\text { Area } \\
\text { (thoussend } \\
\text { square } \\
\text { nito- } \\
\text { meters) } \\
\end{array}$} & \multicolumn{2}{|c|}{ GNP Por Capita } & \multirow{2}{*}{\multicolumn{2}{|c|}{$\begin{array}{l}\text { Average Annual } \\
\text { Rate of Intiation }\end{array}$}} & \multirow{3}{*}{$\begin{array}{c}\begin{array}{c}\text { Adutt } \\
\text { Literecy } \\
\text { Ratec }\end{array} \\
\frac{\text { (percent) }}{1975}\end{array}$} & \multirow{3}{*}{$\begin{array}{l}\text { Life Ex. } \\
\text { pectency } \\
\text { at Birth }\end{array}$} & \multirow{2}{*}{$\begin{array}{l}\text { Index of Por } \\
\text { Capila Food } \\
\text { Production, } \\
1960-71 \\
=100\end{array}$} \\
\hline & & & \multirow{2}{*}{$\frac{\begin{array}{c}\text { (US } \\
\text { dollers) }\end{array}}{1077}$} & \multirow{2}{*}{$\begin{array}{l}\text { Average } \\
\text { Annual } \\
\text { Growth } \\
\text { (per: } \\
\text { cent) } \\
\text { ichart }\end{array}$} & & & & & \\
\hline & & & & & $180-100$ & 1970.770 & & & Av. 1975-77 \\
\hline \multicolumn{2}{|l|}{ Low ineeme Ceuntrie (v) } & & 170 & 1.4 & & & 3 & 50 & 9 \\
\hline $\begin{array}{l}\text { Bnutan } \\
2 \text { Cambodia } \\
3 \text { Bangladesh } \\
4 \text { Lao PDR } \\
5 \text { E!niopia } \\
\end{array}$ & $\begin{array}{r}1.2 \\
8.4 \\
81.2 \\
3.2 \\
30.2 \\
\end{array}$ & $\begin{array}{r}47 \\
191 \\
144 \\
237 \\
1.222\end{array}$ & $\begin{array}{r}80 \\
90 \\
30 \\
110\end{array}$ & $\begin{array}{r}-0.2 \\
-0.4 \\
1.7 \\
\end{array}$ & $\begin{array}{l}3.8 \\
3.7 \\
2.7\end{array}$ & $\begin{array}{r}17.4 \\
\quad 3.3 \\
\end{array}$ & $\begin{array}{l}22 \\
10 \\
\end{array}$ & $\begin{array}{l}41 \\
48 \\
47 \\
42 \\
39\end{array}$ & $\begin{array}{l}99 \\
59 \\
96 \\
99 \\
95 \\
9\end{array}$ \\
\hline $\begin{array}{l}5 \text { Malı } \\
7 \text { Nepal } \\
8 \text { Somalia } \\
9 \text { Burundi } \\
10 \text { Chad } \\
\end{array}$ & $\begin{array}{r}6.1 \\
13.3 \\
3.7 \\
4.2 \\
4.2 \\
\end{array}$ & $\begin{array}{r}1.240 \\
141 \\
638 \\
28 \\
1.284 \\
\end{array}$ & $\begin{array}{l}110 \\
110 \\
110 \\
130 \\
130\end{array}$ & $\begin{array}{r}1.0 \\
0.2 \\
-0.4 \\
2.2 \\
-1.0\end{array}$ & $\begin{array}{l}5.0^{-} \\
8.5 \\
4.5 \\
2.8 \\
4.6\end{array}$ & $\begin{array}{r}7.5 \\
7.7 \\
10.2 \\
9.9 \\
6.6 \\
\end{array}$ & $\begin{array}{l}10 \\
19 \\
50 \\
10 \\
15 \\
\end{array}$ & $\begin{array}{l}42 \\
45 \\
43 \\
45 \\
43\end{array}$ & $\begin{array}{l}91 \\
95 \\
88 \\
99 \\
93\end{array}$ \\
\hline $\begin{array}{l}1 1 \longdiv { \text { Rwanda } } \\
12 \text { Upper Volta } \\
13 \text { Zarre } \\
14 \text { Burma } \\
15 \text { Malawi } \\
\end{array}$ & $\begin{array}{r}4.4 \\
5.5 \\
25.7 \\
31.5 \\
5.6\end{array}$ & $\begin{array}{r}270 \\
2.345 \\
677 \\
118\end{array}$ & $\begin{array}{l}130 \\
130 \\
130 \\
140 \\
140\end{array}$ & $\begin{array}{l}1.0 \\
0.6 \\
1.1 \\
0.9 \\
3.0\end{array}$ & $\begin{array}{r}13.1 \\
1.3 \\
29.9 \\
2.7 \\
2.4 \\
\end{array}$ & $\begin{array}{r}13.0 \\
5.1 \\
22.4 \\
15.0 \\
9.2 \\
\end{array}$ & $\begin{array}{r}23 \\
5 \\
67 \\
25 \\
\end{array}$ & $\begin{array}{l}46 \\
42 \\
46 \\
52 \\
46\end{array}$ & $\begin{array}{r}103 \\
94 \\
96 \\
95 \\
101\end{array}$ \\
\hline $\begin{array}{l}16 \text { India } \\
17 \text { Mozambique } \\
19 \text { Niger } \\
19 \text { Vigt Nam } \\
20 \text { Algnanistan } \\
\end{array}$ & $\begin{array}{r}631.7 \\
9.7 \\
4.9 \\
50.6 \\
14.3 \\
\end{array}$ & $\begin{array}{r}3.288 \\
753 \\
1.267 \\
330 \\
647 \\
\end{array}$ & $\begin{array}{l}150 \\
150 \\
160 \\
160 \\
190 \\
\end{array}$ & $\begin{array}{r}1.3 \\
0.9 \\
-1.4 \\
0.2 \\
\end{array}$ & $\begin{array}{r}6.9 \\
2.8 \\
2.3 \\
11.9\end{array}$ & $\begin{array}{l}8.9 \\
3.8 \\
5.5 \\
4.1\end{array}$ & $\begin{array}{r}36 \\
8 \\
87 \\
12\end{array}$ & $\begin{array}{l}51 \\
46 \\
42 \\
62 \\
42\end{array}$ & $\begin{array}{c}99 \\
95 \\
79 \\
100 \\
102\end{array}$ \\
\hline $\begin{array}{l}21 \text { Pakistan } \\
22 \text { Sierra Leone } \\
23 \text { Tanzania } \\
24 \text { Benin } \\
25 \text { Sri Lanka } \\
\end{array}$ & $\begin{array}{r}74.9 \\
3.2 \\
16.4 \\
3.2 \\
14.1 \\
\end{array}$ & $\begin{array}{r}604 \\
72 \\
945 \\
113 \\
66\end{array}$ & $\begin{array}{l}190 \\
190 \\
190 \\
200 \\
200\end{array}$ & $\begin{array}{l}3.0 \\
1.3 \\
2.6 \\
0.2 \\
2.0\end{array}$ & $\begin{array}{l}3.3 \\
2.9 \\
1.8 \\
1.9 \\
1.8\end{array}$ & $\begin{array}{r}15.2 \\
9.8 \\
12.0 \\
8.5 \\
11.8 \\
\end{array}$ & $\begin{array}{l}21 \\
15 \\
66 \\
11\end{array}$ & $\begin{array}{l}51 \\
46 \\
51 \\
46 \\
0\end{array}$ & $\begin{array}{r}101 \\
96 \\
93 \\
92 \\
113\end{array}$ \\
\hline $\begin{array}{l}26 \text { Guinea } \\
27 \text { Haiti } \\
28 \text { Lesotho } \\
29 \text { Madagascar } \\
30 \text { Central African Emp. }\end{array}$ & $\begin{array}{l}5.0 \\
4.7 \\
1.3 \\
8.1 \\
1.9 \\
\end{array}$ & $\begin{array}{r}246 \\
28 \\
30 \\
587 \\
623 \\
\end{array}$ & $\begin{array}{l}220 \\
230 \\
240 \\
240 \\
250\end{array}$ & $\begin{array}{r}1.3 \\
0.1 \\
5.8 \\
-0.2 \\
0.2\end{array}$ & $\begin{array}{l}1.7 \\
4.1 \\
2.5 \\
3.2 \\
4.2\end{array}$ & $\begin{array}{r}4.9 \\
13.3 \\
11.1 \\
10.1 \\
8.3\end{array}$ & $\begin{array}{l}23 \\
40 \\
50\end{array}$ & $\begin{array}{l}44 \\
51 \\
50 \\
46 \\
46\end{array}$ & $\begin{array}{r}86 \\
-\quad 96 \\
97 \\
96 \\
103 \\
\end{array}$ \\
\hline $\begin{array}{l}31 \text { Kenya } \\
32 \text { Mauritania } \\
33 \text { Uganda } \\
34 \text { Sudan } \\
3 j \text { Angota }\end{array}$ & $\begin{array}{r}146 \\
1.5 \\
120 \\
16.9 \\
66\end{array}$ & $\begin{array}{r}583 \\
1.031 \\
236 \\
2.506 \\
1.247\end{array}$ & $\begin{array}{l}270^{\circ} \\
270 \\
270 \\
390 \\
300\end{array}$ & $\begin{array}{l}2.5 \\
3.6 \\
0.7 \\
0.1 \\
2.3\end{array}$ & $\begin{array}{l}1.5 \\
0.8 \\
3.0 \\
3.7 \\
3.3\end{array}$ & $\begin{array}{r}12.4 \\
10.8 \\
18.4 \\
4.0 \\
22 .\end{array}$ & $\begin{array}{l}40 \\
17 \\
20\end{array}$ & $\begin{array}{l}53 \\
42 \\
53 \\
48 \\
41\end{array}$ & $\begin{array}{r}89 \\
70 \\
93 \\
106 \\
89\end{array}$ \\
\hline $\begin{array}{l}35 \text { inconesia } \\
37 \text { Togo }\end{array}$ & $\begin{array}{r}133.5 \\
2.4 \\
\end{array}$ & $\begin{array}{r}2.027 \\
56 \\
\end{array}$ & $\begin{array}{l}300 \\
300 \\
\end{array}$ & $\begin{array}{l}3.3^{\circ} \\
3.8\end{array}$ & 1.7 & $\begin{array}{r}22.0 \\
86 \\
\end{array}$ & $\begin{array}{l}62 \\
16 \\
\end{array}$ & $\begin{array}{l}48 \\
46\end{array}$ & $\begin{array}{r}104 \\
62 \\
\end{array}$ \\
\hline \multicolumn{2}{|c|}{ Midele income counteres (w) } & & 1.140 & 3.6 & & . & 6 & $\infty$ & 100 \\
\hline $\begin{array}{l}38 \text { Egrpt } \\
39 \text { Cameroon } \\
43 \text { Yemen. POP } \\
41 \text { Gnara } \\
42 \text { Honcuras }\end{array}$ & $\begin{array}{r}37.8 \\
7.9 \\
1.7 \\
: 0.6 \\
3.3\end{array}$ & $\begin{array}{l}1.001 \\
475 \\
333 \\
239 \\
112\end{array}$ & $\begin{array}{l}320 \\
340 \\
340 \\
380 \\
+10\end{array}$ & $\begin{array}{r}2.1 \\
2.9 \\
-4.8 \\
-0.3 \\
1.5\end{array}$ & $\begin{array}{l}3.5 \\
2.7 \\
10 \\
3.0\end{array}$ & $\begin{array}{r}7.0 \\
9.8 \\
36.9 \\
55 \\
\end{array}$ & $\begin{array}{l}44 \\
27 \\
30 \\
57\end{array}$ & $\begin{array}{l}54 \\
46 \\
47 \\
48 \\
57\end{array}$ & $\begin{array}{r}97 \\
101 \\
107 \\
85 \\
80\end{array}$ \\
\hline $\begin{array}{l}43 \text { Leria } \\
44 \text { Vigeria } \\
45 \text { Triariard } \\
46 \text { Senegal } \\
47 \text { Yemer Aras Ree }\end{array}$ & $\begin{array}{r}1.7 \\
79.0 \\
43.8 \\
5.2 \\
5.0\end{array}$ & $\begin{array}{l}111 \\
924 \\
514 \\
196 \\
195\end{array}$ & $\begin{array}{l}420 \\
420 \\
420 \\
430 \\
430\end{array}$ & $\begin{array}{r}1.8 \\
3.6 \\
4.5 \\
-0.3\end{array}$ & $\begin{array}{l}1.9 \\
2.6 \\
19 \\
16\end{array}$ & $\begin{array}{r}9.1 \\
: 5.2 \\
9.3 \\
12.1 \\
160\end{array}$ & $\begin{array}{l}1 \\
82 \\
10 \\
13\end{array}$ & $\begin{array}{l}48 \\
48 \\
61 \\
42 \\
47\end{array}$ & $\begin{array}{r}108 \\
92 \\
110 \\
104 \\
100\end{array}$ \\
\hline $\begin{array}{l}48 \text { Philicoines } \\
49 \text { Zambia } \\
54 \text { Conge. Peosles Reo. } \\
51 \text { Paoua New Guinea } \\
52 \text { Phodesia }\end{array}$ & $\begin{array}{l}44.5 \\
5.1 \\
1.4 \\
2.9 \\
5.7\end{array}$ & $\begin{array}{l}300 \\
753 \\
342 \\
462 \\
391\end{array}$ & $\begin{array}{l}450 \\
450 \\
490 \\
490 \\
300\end{array}$ & $\begin{array}{l}2.5 \\
15 \\
1.1 \\
3.4 \\
1.9\end{array}$ & $\begin{array}{l}j .5 \\
i 6 \\
j .1 \\
35 \\
3\end{array}$ & $\begin{array}{r}143 \\
13 \\
10.3 \\
1.2 \\
3.3\end{array}$ & $\begin{array}{l}87 \\
39 \\
30 \\
32\end{array}$ & $\begin{array}{l}60 \\
48 \\
46 \\
48 \\
52\end{array}$ & 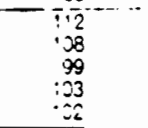 \\
\hline $\begin{array}{l}53 \text { El Salvador } \\
54 \text { Morocco } \\
55 \text { Souvia } \\
56 \text { ivory Coast } \\
57 \text { Jorcan }\end{array}$ & $\begin{array}{r}4.2 \\
19.3 \\
5.2 \\
75 \\
2.3\end{array}$ & $\begin{array}{r}21 \\
4.77 \\
1,099 \\
322 \\
98\end{array}$ & $\begin{array}{l}550 \\
550 \\
030 \\
590 \\
915\end{array}$ & $\begin{array}{l}7 \\
: 2 \\
2.2 \\
3.3 \\
18\end{array}$ & $\begin{array}{l}23 \\
23 \\
23 \\
3 \\
23 \\
1.1\end{array}$ & $\begin{array}{r}9.3 \\
5.3 \\
243 \\
12.3 \\
9.5\end{array}$ & $\begin{array}{l}62 \\
29 \\
53 \\
20 \\
59\end{array}$ & $\begin{array}{l}63 \\
55 \\
52 \\
46 \\
56\end{array}$ & $\begin{array}{r}\because 1 \\
19 \\
\because 13 \\
i 15 \\
71\end{array}$ \\
\hline $\begin{array}{l}56 \text { Coiomoia } \\
59 \text { Puagijar } \\
\text { 50 Ẽador } \\
\text { bi Guatemaia } \\
52 \text { Korea. Reo of }\end{array}$ & $\begin{array}{r}215 \\
2.8 \\
\vdots 3 \\
34 \\
30.0\end{array}$ & $\begin{array}{r}1.139 \\
137 \\
284 \\
139 \\
99\end{array}$ & $\begin{array}{l}720 \\
730 \\
790 \\
790 \\
920 \\
\end{array}$ & $\begin{array}{l}2.7 \\
2.4 \\
2.9 \\
2.9 \\
7.4\end{array}$ & $\begin{array}{r}11.9 \\
30 \\
0.1 \\
167 \\
\end{array}$ & $\begin{array}{l}9.4 \\
214 \\
12.3 \\
: 5.2 \\
10.4 \\
174 \\
\end{array}$ & $\begin{array}{l}81 \\
81 \\
80 \\
74 \\
46 \\
91\end{array}$ & $\begin{array}{l}62 \\
62 \\
63 \\
60 \\
57 \\
63\end{array}$ & $\begin{array}{l}: 07 \\
104 \\
100 \\
113\end{array}$ \\
\hline 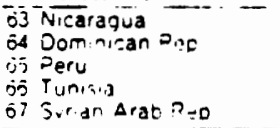 & $\begin{array}{r}2.4 \\
30 \\
i 0.4 \\
59 \\
73\end{array}$ & $\begin{array}{r}130 \\
49 \\
1.265 \\
164 \\
195\end{array}$ & $\begin{array}{l}830 \\
340 \\
340 \\
360 \\
910\end{array}$ & $\begin{array}{l}2.5 \\
3.6 \\
2.3 \\
+3 \\
2.3\end{array}$ & $\begin{array}{l}99 \\
21 \\
93 \\
3.7 \\
1.9\end{array}$ & $\begin{array}{r}119 \\
86 \\
13.3 \\
1.2 \\
1.5\end{array}$ & $\begin{array}{l}57 \\
67 \\
72 \\
36 \\
53\end{array}$ & $\begin{array}{l}55 \\
60 \\
56 \\
57 \\
57\end{array}$ & $\begin{array}{r}103 \\
32 \\
37 \\
31 \\
140\end{array}$ \\
\hline
\end{tabular}

From the The Werld development Repor:, !Washington J. C.: The World Bank, 1979.), 126-127. 


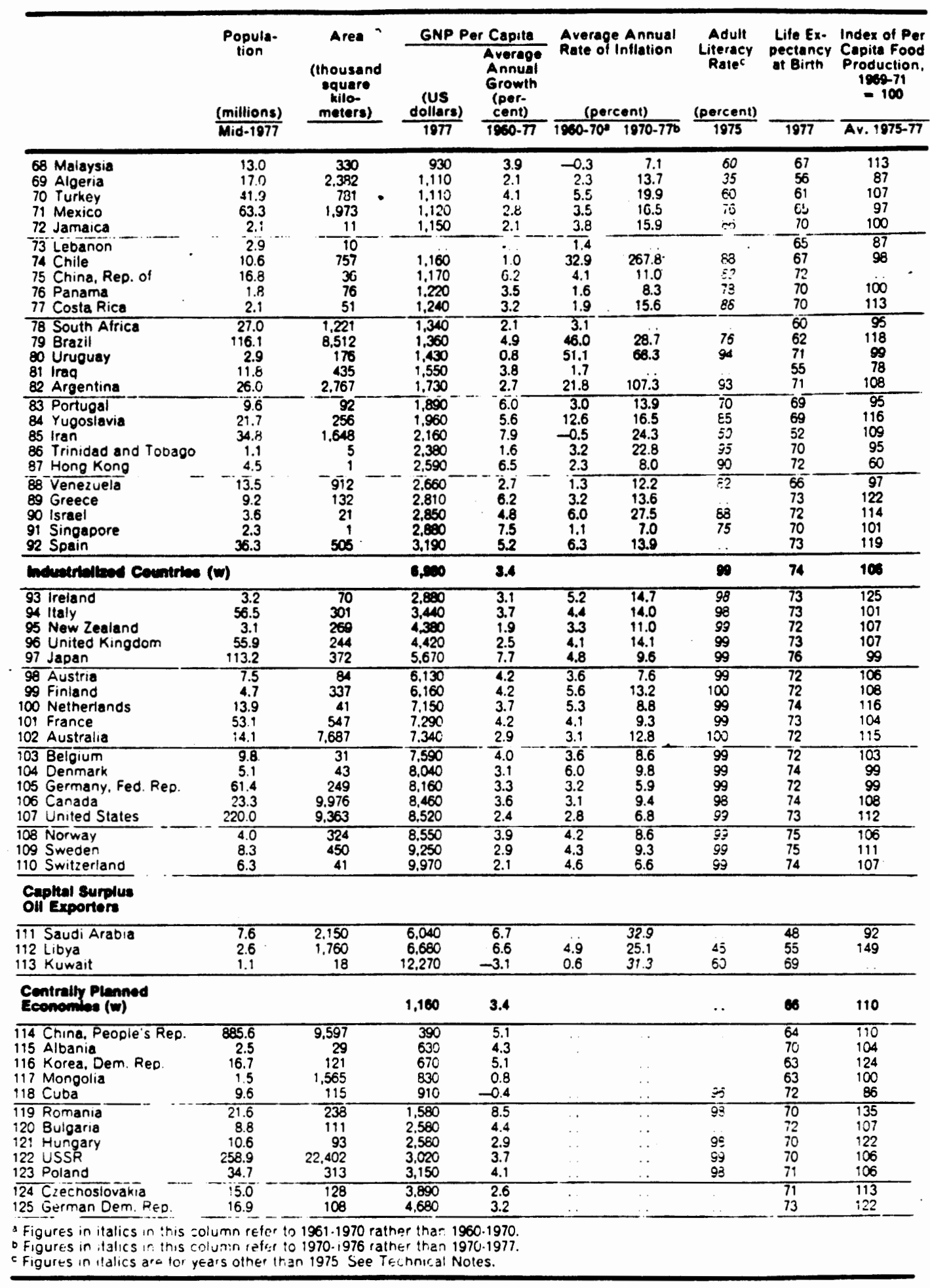




\section{NOTES}

1. The United States provided 458 of the world economic output and 508 of the total manufacturing output. Neville Meaney, "American Decline and American Nationalism," in Australian Journal of International Affairs 45, May 1991: 80.

2. Robert 0 . Keohane, After Hegemony, (Princeton: Princeton University Press, 1984), 183.

3. Robert Gilpin, The Political Economy of International Relations, (Princeton: Princeton University Press, 1987), 130 .

4. Gilpin, 131.

5. Marc Williams, Third World Cooperation: The Group of 77 in UNCTAD, (London: Pinter Publishers, 1991), 18.

6. Geir Lundestad, Major Developments in International Politics 1945-1986, (Oslo: Norwegian University Press, 1986), 267. Bransilav Gosovic, UNCTAD: Conflict and Compromise, (Leiden, Neth.: A.W. Sijthoff, 1972), 3.

7. Richard Gardner, "The United Nations Conference on Trade and Development," in ed. Richard N. Gardner and Max F. Millikan, The Global Partnership, (New York: Frederick A. Praeger, 1968), 102 .

8. Gosovic, 9-12.

9. Robert H. Jackson, "Quasi-States: Dual Regimes, and NeoClassical Theory: International Jurisprudence and the Third World," International Organizations 41 (August 1987): 526 .

10. Jackson, 526-527.

11. Stephen Krasner, Structural Conflict, (Berkeley: University of California Press, 1985), 3,11.

12. Krasner, 11.

13. Robert Rothstein, The Weak in the World of the Strong, (New York: Columbia University Press, 1977), 251.

14. Krasner, 89. 
15. Membership had grown to 128 members by 1993. (Williams, Coalition, 13.)

16. Herb Addo, ed., Transforming the World-Economy. (London: Hodder and Stoughton, 1984), 143 .

17. Rothstein, Weak, 127-128.

18. K.J. Holsti, International Politics: A Framework for Analysis, (Englewood Cliffs, NJ: Prentice-Hall, 1972) as cited in James A. Caporaso, "The External Consequences of Regional Integration for Pan-European Relations," International studies Quarterly 20, (September 1976): 364 .

19. Joan Edelman Spero, The Politics of International Economic Relations, (New York: St. Martin's Press, 1985), 170 .

20. Lundestad, 262-264. Gilpin, 264-269.

21. Gunnar Myrdal, Rich Lands and Poor, (New York: Harper \& Brothers Publishers, 1957). Cited in Lundestad, 264.

22. Spero, 172 .

23. Spero, 173-176.

24. Spero, 172.

25. Gilpin, 283.

26. Krasner, 88 .

27. Williams, 31.

28. Gardner, 102-103..

29. Williams, 32 .

30. Williams, 32 .

31. Gardner, 107.

32. Although GATT was created as a contractual arrangement, it began to operate as a permanent organization, existing independent of the U.N.. Gosovic, 11.

33. Gosovic, 36-39.

34. Gosovic, 40-42.

35. Krasner, 89., 
36. This group was to later become the Group of 77 .

37. Joint Declaration of the Seventy-Seven Developing countries at the Conclusion of the United Nations Conference on Trade and Development, reprinted in Karl P. Sauvant, Group of 77, The Third World Without Superpowers, vol 1., (New York: Oceana Publications, 1981), 20.

38. Karl P.Sauvant, The Group of 77: Evolution, Structure, and Organization, (New York: Oceana Publications, 1981), 13. By the early 1970s, the NAM changed its primary attention to economic matters and "completed the de facto coalescence of the Group of 77 and the Non-Aligned Movement." Krasner, 89.

39. Williams, 33 .

40. Sauvant, Evolution, 2 .

41. Proceedings of the United Nations Conference on Trade and Development, Geneva, 23 March-16 June 1964, vol. I, Final Act and Report, (New York: United Nations, 1964), 17-65.

42. Gardner, 115.

43. Williams, 43 .

44. G.A. Res 3201 (S-VI),6 (Special)U.N. GAOR Supp. (No.1) at 3, U.N.DOC.A/9556(1974).

G.A. Res 3202 (S-VI),6(Special)U.N. GAOR Supp.(No.1) at 5 , U.N.DOC.A/9556 (1974).

G.A. Res 3281 (XXIX),29U.N. GAOR Supp.(No.31) at 50, U.N.DOC.A/9361(1974).

45. Sauvant, Evolution, 5.

46. Edwin P.Reubens, ed., The Challenge of the New International Economic order. (Boulder, Colo.: Westview Press, 1981), 5.

47. G.A. Res 3201. G.A. Res 3202 .

48. G.A. Res. 3201 .

49. G.A. Res. 3202, II.

50. I. William Zartman, Positive Sum: Improving North-South Negotiations, (New Brunswick: Transaction Books, 1987), 3 .

51. G.K. Helleiner, The New Global Economy and Developing Nations, (Aldershot, Eng.: Edward Elgar, 1990), 34-39. 
52. Spero, 209.

53. Michael P.Sullivan, Power in Contemporary International Politics, (Columbia,s.C.: University of South Carolina Press, 1990), 211.

54. Hans J. Morgenthau, and Kenneth W. Thompson, Politics Among Nations 6th ed., (New York: Alfred A. Knopf, 1985), 110 .

55. Spero, 234 .

56. In the OPEC episode, developing countries did successfully threaten the North, however the cartel operated for the good of the oil-producing nations not the Third World. 
CHAPTER IV

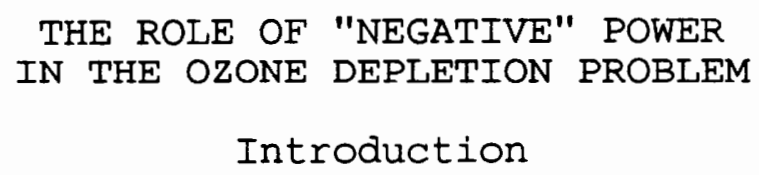

Introduction

The solidarity and confrontational tactics employed by the South in the General Assembly allowed it to bring the issue of underdevelopment to international attention. However, although these tactics enabled developing nations to pass resolutions such as the NIEO, the weakness of Third World nations precluded their implementation. Although sovereign equality granted the Third world some control over the international agenda, nonbinding resolutions present no threat and can be ignored by the North. This inability to threaten is the essence of the weakness of the Third World. However, the situation may be changing; global environmental issues may be the threat that empowers the south vis á vis the North.

Like the power of sovereign equality, the South's power in environmental matters is predicated upon solidarity among the members of the bloc. Yet, while the power of sovereign equality resides in the collective membership, the south's environmental power exists in individual member nations. For example, in environmental negotiations regarding rain forests, tropical nations such as Brazil hold the power. In negotiations concerning energy, OPEC member states hold it. International talks that center on pollution as a by-product of industrialization, yield power to the most populous 
developing nations, i.e., India and China. ${ }^{1}$

Because this power on environmental issues resides in member states, it may be severely undercut by side-agreements between the North and individual developing nations. The unity of the South is vulnerable. In terms of the three types of goals discussed by Rosecrance, material, ideological, and security, ${ }^{2}$ the goals of the south are of the material type and rank the lowest among state objectives. Solidarity such as that of the South is dependent on a nation's perception that its interests coincide with that of the bloc.

International environmental problems of the late twentieth century are increasingly perceived as serious threats by large and small nations alike. In the past, nations dealt with environmental problems through legislation at the national level, or unilateral action at the international level. 3 However, given the global nature of environmental problems today, national legislation and unilateral international action become less and less adequate. Nations increasingly turn to international environmental diplomacy to solve problems that no one nation, even a superpower, can hope to solve alone. ${ }^{4}$

In seeking international solutions to world problems, nations will often group together based on common interest. The political and military forces of the mid-twentieth century caused nation-states to align into East and West. It appears that the economic and environmental forces of the late- 
twentieth century have resulted in a North-South alignment. According to Marc Williams:

It is widely accepted that global negotiations on the environment have a North-South dimension. North-South issues are inscribed in the international environmental agenda at two structural levels: in the equality of responsibility for environmental degradation and in the relative abilities to cope with these problems. ${ }^{5}$

\section{North versus South \\ Environment versus Development}

The environmental issue between North and South can be reduced to the dichotomy of environmental protection versus economic development. The North, having damaged the environment in the process of its own development, now proclaims the need to protect it from further degradation. The developed nations urge the South to avoid the same path of industrialization that produced a high living standard while harming the environment. The Third world takes the position that the industrialized nations are responsible for the damage thus far, and the mistakes of the North should not affect the South's development. Furthermore, without technological aid, and international economic reforms, "the people of the South will have no option but to pollute to survive."6

In 1968 in his seminal work, "The Tragedy of the Commons," Garrett Hardin employed the image of herdsmen keeping cattle on a commons, to explain man's tendency to exploit the environment in order to increase his personal gain. ${ }^{7}$ In this scenario, individuals risk overgrazing the 
commons by continuing to add cattle to their own herds. Each individual acts rationally, since the increase in private goods (well-fed cattle) benefits solely him, while the decrease in the public goods (the environment) is spread among the group.

The North-South environment vs. development theme can be seen as a variation upon this scenario. In this adaptation, there are two groups of herdsmen on the commons. The individuals of the first group, realizing the advantage to be gained, increase the sizes of their herds; however, at some point their actions endanger the commons itself. The second group of herdsmen had at first been unable to expand their herds like the others, and do not share in their increased wealth. When they are able to add to their herds, they are warned by the first group that the pasture is already nearly overgrazed and there is not room for more cattle. The first group stresses the need to preserve the commons for the good of all.

Similarly, the North increased its private goods through a process that decreased a public, though finite good--the ability to pollute without endangering the global environment. The South, now wishing to increase its own private goods by drawing upon that finite resource, learns that there is probably not enough to go around. Does the South have the right to pursue it own development at the risk of the commons?

As long as the North continues to respect the sovereignty 
of the developing nations, negotiation remains the only avenue through which it may influence the behavior of the South. The North's need to negotiate environmental solutions with the South, provides the developing nations "with a new source of leverage and bargaining power. This power is essentially 'negative' and derives from the ability of the south to undermine agreements on global environmental issues."8 Negative power represents a new form of power in world politics, and results from the increasing importance of worldwide environmental problems. Because of the natural resources, land area, and growing populations of the south, it has become a prime beneficiary of this new power.

To illustrate both the scope and limits of this negative power in environmental matters, this chapter and the next will look at two international environmental problems and the conferences that sought to deal with them. This chapter will discuss the matter of stratospheric ozone depletion and the Montreal Protocol (1987). The next one will look at the global warming issue and the United Nations Conference on the Environment and Development(1992). In each case, I will analyze the purpose of the conference, look for any issues that might produce a North-South alignment, and ask whether the South gained any real concessions from the North.

Like the power of sovereign equality, this power is not quantifiable by traditional measures of power. Instead, it is a function of the increasing importance of environmental 
problems. This paper hopes to show that such concessions evidence the negative power of the south. Furthermore, this power will only be operative in situations in which three requirements are met: the North must perceive a serious threat to itself, the South must have influence over that threat, and the South must maintain solidarity in the course of negotiations.

Background to the Montreal Protocol

The United Nations Conference on the Human Environment

The groundwork for the Third World's efforts at Montreal, was laid back in Stockholm, Sweden in 1972. There, eight years after the first meeting of UNCTAD in 1964, and two years prior to the passage of the NIEO, the world would meet to discuss the worsening problems of pollution. The result of the conference, the Stockholm Declaration, would establish the need for differential treatment of developing nations on environmental matters. Differential treatment for developing states would become an integral part of the Montreal Protocol.

Although some argued that developing nations should be excluded from a worldwide conference on the environment, the U.N. auspices of this conference ensured participation by the South. ${ }^{9}$ U.N. sponsorship again proved key to the South, when it used its voting strength in the General Assembly to link the issues of the environment and development. ${ }^{10}$ A preconference committee issued the so-called Founex Report ${ }^{11}$ stating that environmental problems were the result of both poverty and industrialization. This overt recognition of the 
necessity to link environment and development represented a change from the past. "The Founex Report marked the turning point in the definition of the international environmental problem."12

The nations of the South believed that the push to solve environmental problems could seriously affect their ability to become more developed. They made this issue an integral part of the discussions before and during the stockholm talks. ${ }^{13}$ Developing nations believed that environmental problems could not be addressed independent of development problems. An Indian representative at Stockholm stated, "To the majority in these countries, 'environment' is a term that stands for a mud hut providing inadequate shelter against the elements . . Economic development for us is thus not the cause of environmental inadequacies but the cure."14

The conference issued the Stockholm Declaration on the Human Environment. Principle 21 of this document expressed the South's concern that their development not be impeded. According to it, states have the right to exploit their own resources as long as they do not cause damage to another state. ${ }^{15}$ This point strikes a balance between the sovereign right to exploit one's own resources and the sovereign right not to be harmed by another state's action.

Another point on the South's agenda that was successfully incorporated into the Declaration is embodied in Principle 23. Developing nations had argued that it would be inequitable to 
apply environmental treaties equally to every country. Developed nations are more guilty of causing the problem, and compliance is a greater hardship on developing countries. This principle states that ". . . it will be essential in all cases to consider. . . the applicability of standards which are valid for the most advanced countries but which may be inappropriate and of unwarranted social cost for the developing countries."16

The language of Principle'23 differed from all prior international environmental accords in that it specifically distinguished between the obligations of developed and developing countries. "There are no instances of conventional environmental norms or generally known environmental aspirations that provided differential treatment prior to Principle 23 of the Stockholm Declaration on the Human Environment."17 This principle of differential norms is found in many treaties written since Stockholm, in particular, the Montreal Protocol.

The only reason that the developed nations agreed to these principles is that the Stockholm Declaration is just that, a declaration and not a legally binding treaty. Since this type of document is not "hard" law, it has been referred to as "soft settlement". ${ }^{18}$ There are those that argue that in this case soft settlement did in fact become international law. "The general acceptability of those norms by the international community, and especially their translation into 
national laws and subsequent treaties, makes tenable the argument that the prescriptions of the Stockholm Declaration are customary rules of international law."19

Declarations, such as the one at stockholm, may serve as "signposts on the way to customs and treaties."20 By accepting the idea of differential treatment, the UNCHE established a precedent for future global environmental negotiations. The Montreal Protocol adopted the notion of differential treatment, and codified it into international law.

The Problem of Ozone Depletion

The Montreal Protocol serves as the best illustration of a subsequent environmental treaty providing special treatment for developing countries. ${ }^{21}$ This treaty, intended to reduce ozone depletion, provided developing nations with a separate timetable as well as financial aid from the industrialized nations.

Because of the anarchic nature of the international system, cooperative efforts, such as environmental treaties, are difficult to accomplish. A decision to cooperatively deal with a given environmental problem, such as ozone depletion, will only be undertaken if the likelihood of success is high. The combination of several factors worked to increased the likelihood of success. 22 First of all, the scope of the problem was manageable. "The ozone problem appears to be more tractable and more amenable to resolution [than global 
warming]. That may be because CFCs, the main offenders, are less vital to core functions of society, and because they can be controlled by regulating a single industry."23 The relative ease with which the ozone problem could be solved, greatly heightened the negotiation's chances of success.

A second factor leading to success, was the scientific consensus that gradually evolved concerning ozone depletion. At the time of the Protocol's signing, scientists suspected but had not definitively proven that chlorofluorocarbon (CFC) emission resulted in ozone depletion. The release of a major scientific report in 1988 confirmed the earlier theories regarding ozone depletion. The NASA/NOAA document definitively proved significantly decreased levels of ozone. Although the report failed to directly implicate CFCs, the ozone loss was attended by high levels of the chlorine of CFCs. ${ }^{24}$ By confirming the theory of the ozone threat, this report would be instrumental in building international support for accession to the treaty.

The third factor in the success of the Protocol was the support of the major actors: states, nongovernmental organizations, international organizations, and, eventually, industry. ${ }^{25}$ Shortly after the release of the NASA report, Dupont, a major manufacturer of CFCs, announced it would discontinue production of CFCs. Although the company cited environmental reasons for its decision, it "has been a leader in the search for substitutes, which experts say could become 
a major new source of company sales."26 Dupont's stance on the ozone problem was, at least in part, related to its bottom line.

The support of the chemical industry is directly tied to the final factor, the availability of substitutes. While a safe, lowcost substitute was not yet available when the first nations signed the protocol, industry had been working on a substitute since the mid-1970s. This research increased as the likelihood of a CFC ban rose. ${ }^{27}$ The above four factors would prove strong enough to overcome the natural, decentralizing forces of the international system and result in the international prohibition of CFCs.

The Effort to Ban ChIorofluorocarbons

By the time of the Montreal Protocol, CFCs had become an integral part of life in an industrialized society. First discovered by General Motors in 1931, CFCs were employed in refrigeration, air conditioning, insulation, and later, electronics. Although concern for the ozone layer had originally arisen from the prospect of commercial supersonic flights, in 1974, scientists theorized that CFC emissions also damaged the ozone layer. Depletion of the ozone layer could be harmful to marine life and result in increased cancer in humans. ${ }^{28}$

Despite the absence of conclusive scientific data, the severity of the threat and increasing scientific evidence had produced an international consensus on the need to address the 
problem. An international conference met in Vienna in 1985 to try to resolve the problem. Two opposing blocs emerged there, one led by the EEC and the other, the Toronto group, led by the United States. These two factions were unable to agree on proposed actions to reduce the level of CFC emission. Instead of an accord binding states to specific actions, the conference chose to sign a general, nonbinding agreement - the Vienna Convention for the Protection of the Ozone Layer. The treaty, actually a framework for future action, called for international cooperation, research, and information sharing. ${ }^{29}$

Continuing concern for the ozone layer, increasing scientific knowledge, and ongoing negotiation among the parties led to the signing of a protocol in september of 1987 . While the Vienna Convention served as a general framework and established monitoring procedures, the Montreal Protocol actually committed states to concrete and measurable actions to reduce the rate of ozone depletion.

While the Stockholm Declaration stated the importance of treating developing nations differently from developed ones, "the Montreal Protocol is highly unusual, perhaps unique, because it defines "developing countries." 30 Because the Protocol goes on to treat developing and developed nations differently, this definition is a key aspect of the treaty.

Because development has been synonymous with the use of CFCs, the "developed" nations are at much greater fault for 
the current ozone depletion problem. In 1986, the developed nations consumed 848 of the CFCs produced; developing nations accounted for only 168 (of which the populous nations of China and India make up only 28). ${ }^{31}$ Even if the Montreal Protocol proved successful in substantially reducing the $84 \%$ created by developed nations, future industrialization and modernization by populous Third World nations would severely undercut the effort by the North. As Third World nations seek the basic comforts of modern life, such as refrigeration, their increased consumption of CFCs seriously threatens the ozone layer. ${ }^{32}$ Thus, the underlying North-South conflict: environmental protection or economic development?

In an effort to provide both protection and development, the Protocol contains differing goals for developed and developing nations. Article 2 of the Protocol describes the different timelines and reduction levels for developed and developing countries, while Article 5 sets the criteria by which a state is considered to be developing. To accommodate the increasing industrialization of developing nations, their rate of reduction is less rapid and their phaseout period is extended.

\section{Gaining the Support of the South}

As it turned out, Article 5 insufficiently addressed the concerns of developing nations. While the major industrialized nations agreed to the Protocol, there were significant absences from the developing world. of the 
twenty-four nations that signed, most were industrialized nations. China and India, representing 1.9 billion people or 378 of the world's population, ${ }^{33}$ served notice they would not be signing the accord.

Accumulating scientific evidence highlighted the need for accession by the Southern nations. Whereas the negotiations prior to 1987 had taken place largely among Northern nations, after the major industrialized consumers had signed on, the ozone depletion issue took on a strong North-South character.

The weight of scientific evidence and the availability of CFC substitutes caused the North to move with increasing speed toward total phaseout of CFCs. This prospect affected the position that had been adopted by the developing countries at Montreal. Richard Benedick, the American negotiator at Montreal, writes:

By 1989 the objectives of the developing-country negotiators had undergone significant change. At Montreal their preoccupation, reflected in the negotiations over article 5, was primarily to maintain maximum usage of CFCs for the longest possible grace period. But with the industrialized countries now on a fast track toward phaseout . . . it would now be in the interest of developing countries . . . to move as rapidly as possible to new technologies--and to ensure that help was available to accomplish this. ${ }^{34}$

This change of strategy on the part of the developing countries, meant that the Montreal Protocol, as it stood, failed to address their concerns.

The Protocol's differential treatment of developing nations was intended to allow them to continue to modernize 
with CFC technology. However, the rapidity of phaseout in the North, would obsolete some of the CFC technology. It made little sense for the Third World to modernize with obsolete technology. The South saw the need to acquire the new, and probably more expensive technology. Accordingly, it now negotiated for adequate financial assistance and "preferential and noncommercial transfer of technology." 35

A series of international negotiations, from 1988 to 1990, discussed the question of technological and financial aid for the developing nations. China and India, both nonparties to the original agreement, insisted on the creation of a technology transfer fund to provide them with access to nonpolluting technology. ${ }^{36}$ They saw ozone depletion as a problem of the developed world and demanded that the industrialized nations pay for the harm they had done. The Indian Environment Minister stated: "Lest someone in this conference think of this as charity, I would like to remind them of the excellent principle of 'polluter pays' adopted in the developed world." 37

Although the Montreal Protocol contained provisions restricting $C F C$ trade between parties to the treaty and nonparties, the large populations of India and China ensured a market for their domestic CFC production. If they chose to, these two giants of the developing world could continue to destroy the ozone. A 1989 editorial in the journal, South, wrote as follows: 
Unless a technology transfer fund is started to help developing countries switch to safer chemicals, such countries as China and India will have no alternative but to continue producing and using CFCs for refrigeration, air-conditioning, and other essential uses. And without international economic reforms the people of the South will have no option but to pollute to survive. ${ }^{38}$

A number of contentious issues surrounded the topic of funding, including the question of "additionality," and the voting procedure of the executive committee. Additionality referred to whether the funds donated by the industrialized nations would be in addition to existing financial aid or in place of it. At one point, the Bush administration reversed the American position on additionality, refusing to pledge additional funds. Because the U.S. had been the leader of the international movement to reduce CFC emissions, this sudden change of stance jeopardized the success of the treaty itself. ${ }^{39}$ The matter was settled at a London conference held in 1990. Responding to both domestic and international pressure, the United states dropped its opposition to additionality and the establishment of a new multilateral fund. ${ }^{40}$

Incentives were also formalized in agreements reached in London for commitments to technology transfer, and (pending the creation of a permanent Financial Mechanism) for the establishment of an Interim Multilateral Fund. - contributed principally by developed states to aid the implementation of the Protocol through non-ozonedepleting development in developing countries which are
parties. ${ }^{11}$

Following U.S. agreement to the funding mechanism, China gave 
indications that it would sign the revised protocol. With China's agreement, considered a breakthrough, India remained the last major developing country not a signatory to the treaty. ${ }^{42}$

The voting procedure of the executive council to administer the fund, developed into another North-South issue. The matter of voting relates back to the doctrine of sovereign equality and majoritarian rule. Because the committee would be empowered to act only in a narrow area, majoritarian rule based on sovereign equality could be considered. As discussed in Chapter 3, the large number of Third World states allows them to dominate international bodies that vote solely according to sovereign equality. In an effort to restrict this type of power, the developed states originally sought to adopt consensus voting for the executive committee. This would have avoided the majoritarian situation of the United Nations General Assembly.

The developing countries, of course, preferred "a straightforward two-thirds majority rule."43 The eventual decision represented something of a compromise in which both sides won the ability to block action. Decisions would be adopted by a two-thirds majority of all nations present, along with a simple majority within both the developed and developing blocs. ${ }^{44}$ This issue pitted the negative power of the South against the economic power of the North--and a compromise was the result. Given the traditional weakness of 
the South, even a compromise can be considered a victory.

\section{Summary}

The overpowering military and economic strength of the North has always placed it in a predominant position in its dealings with the weaker nations of the South. While the Stockholm Declaration set a precedent by adopting the concept of differential treatment, the agreement's nonbinding status greatly undercuts the impact of this concession. However, the inclusion of the concept in the Montreal Protocol, demonstrates how nonbinding agreements can serve as "signposts" for future international law.

Global environmental negotiations often divide along North-South lines because of the nature of pollution. North and South often differ as to who is at greatest fault and who should pay to correct the damage. The South won concessions from the North because the situation met the three requirements of negative power. The North became convinced that ozone depletion represented a serious threat. The South's choice of a path to industrialization would have a major effect on the ozone depletion problem. And, those Southern nations with the greatest leverage, in particular, India and China, maintained solidarity with the bloc.

Because of the negative power of the South, the North agreed to the establishment of a new multilateral fund, it agreed to additionality, and it agreed to "special" majoritarian voting on the Executive Committee. Given the 
traditional weakness of the South, these concessions demonstrate the presence of some power other than military and economic. The concessions confirm the existence of the "negative" power of the south, that is, its ability to withhold its agreement on matter of international cooperation deemed critical by the North. The next chapter will evaluate the effect of this power in the global warming talks at the Rio Summit in 1992 . 


\section{NOTES}

1. While China is often considered a developing nation, it is not formally a member of the Third World (as defined by the NAM and the Group of 77.) Nevertheless, China often acts a spokesperson for developing nations in global negotiations. Marc Williams, "Re-articulating the Third world Coalition," Third World Ouarterly 14 (1993) : 21 .

2. See Chapter 1, fn 10. Richard Rosecrance, International Relations: Peace or War, (New York: McGraw-Hill, 1973), 208209 .

3. Richard Benedick, Ozone Diplomacy, (Cambridge: Harvard University Press, 1991), 3.

4. "Two multilateral environmental treaties came into force in the United States between 1940 and 1959; ten between 1960 and 1979; 11 in the 1980's alone." (Anonymous, "Whose World Is It Anyway," The Economist 323, (May 30, 1992): 6.

5. Williams, "Re-articulating," 25.

6. South 102, "The hole in the ozone logic," (April 1989): 9 .

7. Garrett Hardin, "The Tragedy of the Commons," Science 162 (December 3, 1968).

8. Andrew Hurrell and Benedict Kingsbury, eds., The International Politics of the Environment, (Oxford: Clarendon Press, 1992), 41.

9. One school of thought, led by George Kennan, sought to exclude the developing nations from a conference on world pollution. Kennan reasoned that the developed world both caused the pollution and could best correct the problem. The involvement of developing nations would only slow down the effort. Kennan reversed this line of thought as the United Nations Conference on the Human Environment (UNCHE) approached, agreeing that all nations should be present. New York Times, "Kennan Now Backs An Agency in U.N. on world Pollution," (March 3, 1972): 8 .

10. Williams: 20 .

11. Development and Environment: The Founex Report: In Defense of the Earth, The Basic Texts on Environment (UNEP Executive Series 1, Nairobi, 1981). Cited in Peter $S$. Thacher, "The Role of the United Nations," in Hurrell and 
Kingsbury, 188.

12. Williams: 18 .

13. New York Times, "Struggling Against the Doomsday Timetable," (June 11, 1972): IV, 7, 8.

14. Mostafa Tolba, ed., Evolving Environmental Perceptions, (London: Butterworths, 1988): 203.

15. U.N. DOC.A/CONF.48/14 \& Corr. 1 reprinted in 11 I.L.M 1416 hereinafter the Stockholm Declaration. Principle 21, 1421 .

16. Stockholm Declaration, Principle 23, 1420.

17. Daniel Barstow Magraw, "Legal Treatment of Developing Countries," Colorado Journal of International Environmental Law and Policy 1, (Summer 1990): 89.

18. Patricia Birnie, "International Environmental Law: Its Adequacy for Present and Future Needs," in Hurrell and Kingsbury, 53.

19. John Ntambirweki, "The Developing Countries in the Evolution of an International Environmental Law," Hastings International and Comparative Law Review 14 (Fall 1990): 909.

20. Birnie, 83 .

21. Ntambirweki, 910.

22. Peter Morrissette, "The Montreal Protocol: Lessons for Formulating Policies for Global Warming," Policy Studies Journal 19, (Spring 1991): 152-157.

23. Lois R. Ember, Patricia L. Layman, Wil Lepkowski, and Pamela Zurer, "Tending the Global Commons," Chemical and Engineering News (November 24, 1986): 14-51.

24. Science 239 "Stratospheric Ozone is Decreasing," (March $25,1988): 1491$.

25. Morrissette, "The Montreal Protocol", 155.

26. Philip Shabecoff, "Dupont to Halt Chemicals That Peril Ozone," New York Times, (March 25, 1988), A1, A20.

27. "Industry Acts to Save Ozone," New York Times (March 21, 1988): A1. Ember, 52. 
28. Peter M. Haas, "Banning chlorofluorocarbons: epistemic community efforts to protect stratospheric ozone," International Organization 46 (Winter 1992): 196-200.

29. Vienna Convention for the Protection of the Ozone Layer, March 1985 as reprinted in Benedick, 218-229.

30. Magraw, 96.

31. Haas, 199.

32. "China produced 7.4 million refrigerators last year; 84 percent more than in 1987, and 133 times more than in 1981." James L. Tyson, "Why China Says Ozone Must Take Back Seat in Drive to Prosperity," Christian Science Monitor (March 23, 1989): 1 .

33. Larry B. Stammer, "Chinese Delegates to Seek Beijing's Approval for Pact to Protect Ozone," Los Angeles Times (June 29, 1990): A8.

34. Benedick, 148 .

35. UNEP, Second Meeting of the Parties to the Montreal Protocol, "Draft Amendment to the Montreal Protocol on Substances that Deplete the Ozone Layer," UNEP/OzL.Pro.2/L.4/Rev.1, London, June 29,1990, 9, cited in Benedick, 189 .

36. South 102 (April 1989): 9.

37. Jonathan C. Randal, "Third World Seeks Aid Before Joining Ozone Pact," Washington Post (March 7, 1989): A16.

38. South 102 (April 1989): 9 .

39. Benedick, 160 .

40. Funding was initially established at $\$ 160$ million dollars for the first three years. This could expand to $\$ 240$ million with the inclusion of more countries. London Revisions to the Montreal Protocol, Annex A, Appendix IV, as reprinted in Benedick, 242-264.

41. Hurrell, 17.

42. Stammer, A8.

43. Benedick, 185 .

44. London Revision, Article 10, paragraph 9. As reprinted in Benedick, 255. 


\section{CHAPTER $V$ \\ NEGATIVE POWER AND \\ THE GLOBAL WARMING NEGOTIATIONS}

The ability of the South to win concessions during the ozone depletion talks, confirmed the existence of a new type of power for the poor, weak states of the South. In order for this negative power of the south to be operative, three conditions must be present: the North must perceive a serious environmental threat, the South must have influence over that threat, and the members of the Southern bloc must successfully resist defection from the group. Under these circumstances, the militarily and economically weak nations of the Third World have sufficient leverage to extract concessions from the powerful North.

The Montreal agreement was deemed a success because it showed that the members of the anarchic, international system could agree to forego short-term gains when faced with the possibility of major ecological damage. Following the successful conclusion of the treaty, "there were calls from the environmental and scientific community for a similar international agreement on the global warming issue."1 Because of the South's growing population and industrialization, the global warming issue seemed to offer it another opportunity to take advantage of its newfound negative power.

Although both ozone depletion and global warming 
represent environmental damage resulting from anthropogenic emissions of greenhouse gases ${ }^{2}$ into the atmosphere, the problems differ significantly. The previous chapter explained how the success of the Montreal Protocol was due to four factors that ultimately reduced the costs for and increased the likelihood of benefits from an agreement. This chapter will compare the global warming and ozone depletion talks; it will look for the presence of North-South issues at the climate change negotiations, and ask whether the conditions existed for the negative power of the South to win concessions from the North.

\section{Background to \\ The United Nations Conference on Environment and Development}

The phenomenon of global warming results from the presence of certain types of gases in the atmosphere, referred to as greenhouse gases (GHG). The presence of these gases, a natural phenomenon, has been beneficial in the past by warming the planet to the point where it supported life. While the presence of greenhouse gases is a natural phenomenon, human existence has always supplemented this supply. By burning biomass to cook, to heat, to light, humans have released additional amounts of the greenhouse gas, carbon dioxide, into the air. The industrial revolution, largely made possible by the combustion of fossil fuels, greatly increased the level of anthropogenic emissions. Up until the time of the industrial revolution, these emissions had been insufficient to 
significantly affect the atmosphere. However, by the late twentieth century, the rates of release had risen to a point where the concentrations of greenhouse gases "were increasing over their natural levels."3

While scientists have known of the warming effect of greenhouse gases since the mid-nineteenth century, it was not until the 1960s and 1970s that they questioned the effects of large increases of atmospheric carbon dioxide. They hypothesized that the rising $\mathrm{CO}_{2}$ levels could result in increased global warming with potentially catastrophic effects. These effects could include "sea-level rise, changed rainfall and storm patterns, with consequent desertification and flooding, agricultural migration . . and perhaps other unpredicted impacts."4

In 1988, due to the growing concern about global warming, the United Nations created a body to study the issue of climate change--the Intergovernmental Panel on Climate Change (IPCC). Two years later, the United Nations followed this by a call for multilateral discussions on a climate change treaty. Noting the threat posed by global warming, the General Assembly established the Intergovernmental Negotiating Committee on a Framework Convention on Climate Change (INC). ${ }^{5}$ An international conference on the environment was to be convened in June of 1992. It was hoped that the INC would have worked out the nuts and bolts of the treaty by that time; only final negotiations and signing would take place at the 
United Nations Conference on Environment and Development (UNCED). The conference was intended to culminate in the signing of five major international agreements on the environment: the Rio Declaration, Agenda 21, Forest Principles, and treaties on biodiversity and climate change. ${ }^{6}$ This chapter will concentrate on the negotiations of the global warming treaty at the INC and UNCED.

\section{North-South Issues of the Conference}

Much of the negotiation for the Earth Summit and parts of the negotiation over global warming were characterized by North-South conflict. The conflict followed a line familiar since Stockholm in 1972. The North asserted the need for a cleaner development process to save the environment. The South responded that the environmental damage had occurred as a result of the North's cheap and dirty path to industrialization. The developing nations, just now venturing down that enriching but polluting path, feel that they enjoy a right to development.

- . if anyone has to put a curb on development, it should be the North and not the South because the South has yet to develop and needs to grow . . . the development of the South can in no way be compromised by the North's preemption of global environment space.?

While environmental talks frequently center on the present pollution of the industrialized North and the future pollution of the industrializing South, development is not the only anthropogenic cause of pollution. Underdevelopment 
itself may damage the environment. "Impoverished people can be as destructive to the environment as industrialization."8 For example, poverty may force people to chop down valuable forests to clear land for subsistence farming. Environmental concerns become secondary to basic concerns for human life.

In the tradition of the Founex Report of Stockholm, the South maintained that the issues of environment and development cannot be considered separately. The wording chosen for the conference name reflects the early drawing of battle lines between North and South. The North envisioned environmental negotiations (the ' $E$ ' in UNCED), while the South insisted that the conference be on the subjects of both environment and development (therefore the ' $\mathrm{D}^{\prime}$ ). The conference name is indicative of many North-South agreements. The final wording simply restates the opposing views rather than indicating a mutually accepted compromise.

Third World nations believe that many of their problems result from their underdevelopment. Since the days of the NIEO, they sought to alleviate this condition through technology transfers, and financial aid from the North. While nonbinding resolutions such as the NIEO proved ineffective in obtaining Northern cooperation, global environmental problems seemed to offer the South new opportunities to press their agenda.

Similar to the ozone depletion problem, ultimate success on a global warming treaty depended upon the agreement of the 
South. As of 1992, the 130 odd developing nations accounted for four-fifths of the world's population and one-sixth of its economic output. ${ }^{10}$ According to the world Resources Institute, the top six producers of greenhouse gases in 1991 were: the United States, the U.S.S.R., Brazil, China, India, and Japan." The growing populations and rising industrialization of the South, could only increase their environmental impact.

A number of developing nations believed that the global warming issue provided them with power over the North. Determined to extract concessions at Rio, the developing nations met at Kuala Lumpur, Malaysia to map out a coordinated strategy for the talks. Recognizing the power of the South on environmental matters, the Prime Minister of Malaysia told G77 members, "Fear of the North of environmental degradation provides the South the leverage that did not exist before. It is fully justified for us to approach it this way."12

Some nations believed that the environmental crisis would provide the South with the opportunity to implement new means of financial transfers. A Wall street Journal article entitled "Rio Agenda: Soak the West's Taxpayers," reported that Brazil and Argentina submitted a list of potential mechanisms to accomplish this transfer. The list included such ideas as a tax on all newspapers, and a special postage stamp called Greenmail (the article made mention of blackmail.) ${ }^{13}$ 
The South's threatened play of the environmental card suffered from two weaknesses. First, if the south chose the dirty path to development, and the global warming threat was real, the vulnerable nations of the South stood to lose more than the North. Second, the "weak administrative and market institutions of the South may prevent them from reaching reduction targets even if they agreed to them."14 While the South had succeeded in gaining concessions at Montreal, the question was, did global warming offer them the same opportunity?

Differences between the Problems of Ozone Depletion and Global Warming

Chapter IV suggested that the success of the Montreal Protocol can be traced to four factors: the manageability of the problem, the availability of substitute technology, the evolution of a scientific consensus, and the lack of opposition by major actors. Although the Montreal accord has been sometimes held up as a model for a global warming agreement, the two issues differ significantly on the basis of these four factors. ${ }^{15}$

In terms of the manageability of the problem, ozone depletion is a much more tractable problem than global warming. Only a handful of gases caused the ozone depletion problem and a small number of companies manufactured them. ${ }^{16}$ Global warming, on the other hand, results from the emission of a variety of greenhouse gases, in particular carbon dioxide, which is a byproduct of the combustion of fossil 
fuels.

As an example of the comparative costs of the two problems, one source estimated the U.S. cost of CFC reduction to be $\$ 2.7$ billion, while the report estimated that a 208 cut in carbon dioxide emission would cost between $\$ 800$ billion and $\$ 3.6$ trillion. ${ }^{17}$ Obviously the reduction of emission sources is a much more expensive problem in the case of global warming than ozone depletion.

While the North's use of fossil fuel is the chief emission source of greenhouse gases, another major source is the burning of biomass by developing nations. But this pollution is the byproduct of the struggle to survive. It can only be addressed by alleviating the poverty of the Third World--vastly increasing the scope of the undertaking.

The ways of life of both developed and developing nations are based upon the burning of carbon and thus indirectly the production of carbon dioxide. To limit carbon dioxide emission, Southern poverty and Northern industrialization must undergo radical change. The future development of North and South is affected differently by substantial reductions of GHGs. "In the industrialized world the issue is one of economic cost, growth, and comparative advantage; in the developing world the issue is more fundamental, entailing delaying or even foregoing economic development."18 This is the nub of the North-South debate on the environment.

The second factor that accounted for the success at 
Montreal was the availability of CFC substitute technology. The effort to find substitute sources for fossil fuel has been both more complicated and less successful. Alternative sources such as nuclear, solar power, geothermal, or hydrogen have not yet demonstrated their cost-effectiveness. The universal usage of fossil fuels and the absence of acceptable substitutes greatly increases the costs of GHG reduction.

The third factor, scientific consensus, highlights another major difference between ozone depletion and global warming. As stated in the last chapter, scientific opinion coalesced behind the ozone depletion theory during the course of the negotiations. However, due to the complexity of the global warming debate, scientific opinion on the merits of the global warming argument remains divided. The IPCC, often considered to be the most authoritative source, issued its First Assessment Report in 1990. While the report did forecast a global temperature increase and sea-level rise, it stated that there are many uncertainties as "to the timing, magnitude and regional patterns of climate change."19

Wilfred Beckerman argues that despite the best efforts of scientists, the global warming phenomenon remains poorly understood. Furthermore, Beckerman states that: "although there are enormous uncertainties in both the science and economics of global warming, the damage done by global warming is likely to be far less than the costs that would be incurred by hasty and draconian measures to reduce GHG emissions."20 
It is not the aim of this paper to argue the merits of the global warming argument; it is sufficient to note that great debate continues to surround the theory.

The last of the four areas in which to contrast the two treaties is that of the opposition of major actors. The Montreal Protocol eventually enjoyed the support of all the major actors involved: governments, IGOs, and industry. Although the North was originally split into two camps, led by the U.S. and the E.C., the increasing weight of scientific argument eventually brought them together. Having achieved consensus among the developed countries, the negotiations took on a North-South character at that point.

Just as they had during the ozone talks, the U.S. and the EC again found themselves on opposite sides. However, in this case, America played the role of the laggard rather than the leader.

The United States, which had taken the lead in efforts to coordinate international action on the most significant global environmental accord to date--the Montreal Protocol dealing with stratospheric ozone depletion-found itself at odds with virtually all the other major advanced industrial nations when it came to accepting firm, binding international commitments as a first step towards averting the environmental catastrophe believed to result from the "greenhouse effect."21

Elements in the climate change issue would cause nations to defect from the North-South alignment that had dominated other environmental negotiations. According to Peter Hayes, "The concepts of 'South' and 'North-South' conflict may be obsolete 
and irrelevant in the climate change arena. Indeed, since late 1991, negotiations over climate change have resulted in a fractured and pragmatic set of political axes."22

\section{New International Alignments}

The negotiations at Rio proved somewhat more complex than those of Montreal because the summit dealt with multiple environmental problems. The differing nature of these problems resulted in shifting coalitions dependent on the issue. The lack of solidarity among North and South strengthens the conception of them as pressure groups rather than blocs.

Parallel negotiating groups worked out the terms of the agreements to be signed at the conference. One group, the Preparatory Committee of UNCED (Prepcom), negotiated the terms of the Rio Declaration and Agenda 21. The broad, nonbinding agreements negotiated by this group, produced the same NorthSouth ethos as the Montreal talks. Another negotiating group, the INC, worked out the terms of the climate change treaty. Rather than re-creating the North-South alignment of the Prepcom talks, "the fault lines in the INC are as often among developed countries as between developed and developing countries." $" 23$

The concepts of North and South applied to the Montreal talks because the discussions eventually resolved themselves into the matter of environment versus development--the North feared for its environment while the South sought to protect 
its future development. At the global warming talks, on the other hand, the presence of crosscutting issues overrode the environment-development dichotomy. The thermal change might cause minimal problems for some nations while devastating others. ${ }^{24}$ For some nations, the potential accord represented a greater threat than the possibility of climate change. Because the global warming issue threatened to impose differential costs on bloc members, national interests did not necessarily correspond to the North-South dichotomy.

The major split within the North occurred between the United States and the other developed nations. The U.S., which had acted as a leader at both the Stockholm and Montreal conferences, opposed a climate change treaty because it "was unwilling to impose a substantial burden on the U.S. economy without significant corresponding benefits."25 The U.S. adopted a position opposed to reduction targets, or timetables by which to achieve them. By virtue of its wealth and superior technology, the U.S. believed that it could adapt to global warming at minimal cost.

Unwilling to follow the American lead on the climate change issue, the EC led the effort among the developed countries to reduce $\mathrm{CO}_{2}$ emissions to 1990 levels by the end of the century. The New York Times reported that:

As the Earth Summit enters its final phase, Europe and Japan are showing increasing independence from the United States on environmental issues, worsening American isolation and creating a diplomatic challenge for 
Washington. 26

The EC-led group came together for varying reasons. Some countries had suffered through trans-boundary acid rain problems. Others joined the group believing that the cleanup effort offered economic opportunities. Others still seemed to share a feeling of responsibility for the environment. ${ }^{27}$

While the North suffered a schism, the South had even greater difficulty maintaining a sense of unity during the negotiations. In an effort to present a united front, delegates of the South met in Geneva in 1991 to craft a common position. To maintain solidarity, this group adopted a platform that stressed the fundamental issues that separated the developed and developing worlds--the South's need for environmental space and economic development. The platform asserted that since the North is largely responsible for the current pollution, environmental problems could not be used as a justification for denying the south the right to industrialize. ${ }^{28}$

Unfortunately for the South, this veneer of solidarity broke apart under the strain of the differential costs of the climate change issue. ${ }^{29}$ As the International Negotiating Committee sought to reach agreement on a climate change treaty in the closing months before the summit, the unity of the G77 dissolved. The small, island nations had formed their own political bloc, the Alliance of Small Island states (AOSIS). These nations, facing submersion if sea-levels should rise, 
advocated radical GHG reductions. At the other extreme were the large energy producers (the OPEC states), and large energy consumers (e.g., Brazil, India, and China). This group opposed a strong accord fearing its effect on their economies. Between these two extremes lay a large bloc of over 40 nations that advocated waiting for the decision of the developed countries. ${ }^{30}$

Because the environmental strength of the south resides in its member nations, the power of the bloc is dependent upon solidarity. The differential impact of the climate change issue destroyed that solidarity as developing nations rediscovered the diversity of their interests. At one extreme were the developing nations that feared the threat of globalwarming, and on the other extreme were those that feared the potential costs of alleviating the threat.

Unable to produce a consensus among their members, the developing nations lost the ability to pose a threat to the North. "The fragmentation of the South places developing countries in a weak bargaining position on the central issues of financing, technology transfer, and compensation payments. - . 1131

Unlike its position during the Montreal talks, the South held little leverage during the negotiations on global warming. The richest, most powerful player, the United States, failed to perceive a serious threat to its interests. Furthermore, the ability of the South to deliver on the threat 
was questionable. And finally, in the face of differential costs to bloc members, the south failed to maintain the required solidarity. Without a plausible threat to the North or the means to carry it out, the south entered the final negotiations from a position of weakness.

The United Nations

Framework Convention on Climate Change

Although authors such as Robert Keohane and Robert Gilpin have written on the decline of American hegemony, ${ }^{32}$ neither the EC nor the South accomplished its negotiating goals in the face of American opposition. U.S. objections to the inclusion of targets or timetables in the treaty, forced the other states to choose between a stronger treaty lacking American participation, or a weaker treaty with it. Rather than go without an American signature, the Europeans agreed to a compromise. They agreed to accept a general framework document rather than a legally binding treaty containing targets and timetables. In exchange, the United States agreed to vague wording calling on all parties to limit their emissions with the "aim" of returning to 1990 levels.33 Environmentalists were critical of the weakened agreement. "The climate treaty is now a shell that will allow continued degradation of the global atmosphere. Faced with an ultimatum from the U.S., the Europeans have abandoned their promise to include binding commitments in the treaty."34

Given the weak negotiating position of the developing nations, it is not surprising that they, like the EC, failed 
to win much in the way of binding commitments. The South did manage to include the notion of differential treatment for developing nations, which had originated in stockholm. Similar to Montreal, they won a commitment for "new and additional financial resources" rather than a re-allocation of existing funds. While the North acceded to the Southern demand to provide "the agreed full costs incurred by the developing country Parties in complying with their obligations," 35 the treaty fails to define these costs leaving the matter open to future interpretation. The South also succeeded in including language that stated that fulfillment of their treaty obligations would be dependent upon the North's fulfillment of its financial obligations. ${ }^{36}$

The question of the institution to administer the financial aid also became a North-South issue. The developed countries favored an expansion of the Global Environmental Facility (GEF), a fund controlled by the World Bank and over which the North had greater control. On the other hand, the developing countries preferred the establishment of a new Green Fund, independent of the World Bank, which would provide the developing nations with greater access. The compromise decision favored the North. The additional financial assistance would be channeled through the GEF; however, it would be reformed to allow greater southern control. ${ }^{37}$ Given the contentiousness of the negotiations and the number of unknowns, the climate change treaty did not 
attempt to establish the level of funding to be provided by the North, but left that for future negotiation.

\section{SUMMARY}

While the South won a few concessions at the climate change negotiations, there was little that was both new and binding. The concessions gained by the South at Montreal were a result of the presence of the three requirements of the South's negative power. The North perceived a vital interest to be at risk - the protection lent by the ozone layer. The South had influence over the threat to the North, future Southern industrialization. And the South maintained its solidarity--the two powerhouses, India and China, consistently acted as spokespersons for the developing nations.

These three requirements were not met at the global warming talks. The United States, the chief player of the North, failed to perceive a threat. The ability of the South to deliberately influence global warming was questionable. And the South failed to maintain any sort of solidarity during the talks. The negative power of the South is necessarily more limited than military or economic power. Although the South threatened "to play a climate destruction card in a slow motion game of global climate change poker,"38 it walked away from the table with empty pockets. 
CHAPTER VI

THE CONCLUSION

While all power is subject to constraints, the negative power of the South is particularly reliant on the presence of certain conditions. The power of sovereign equality and negative power are two of the few sources of Southern strength in the international system. But unlike military or economic strength, the South's powers lack the ability to threaten in and of themselves. The power of sovereign equality is the power to recommend, not to compel; while negative power relies upon the presence of an already existing threat.

The two strengths of the South, sovereign equality and negative power, are not necessarily independent of each other. They can be effective when used together. At both Stockholm and Rio, the Third World used its majority in the General Assembly to ensure that development issues became an integral part of the discussions of the conferences. While both sovereign equality and negative power provide the south with greater international leverage, the battle between North and South continues to be a conflict between vast unequals.

The terminology, "North" and "South," is misleading in itself; it seems to equate this struggle with that other hemispheric confrontation, East vs. West. The fundamental difference between the two struggles lies in the power differential between the blocs. In the East-West conflict, superpowers acted as hegemons for blocs of developed 
countries, in a military and economic struggle. Concern about the confrontation arose because of the terrible strength of the two sides. The North-South conflict, on the other hand, is a struggle which pits the weakest nations against the strongest--international equity, not international destruction, is the issue. Given the weakness of the South, this dispute necessarily takes place at the negotiating table rather than in a battlefield or trade war.

The South's inability to directly threaten, stems from two factors: the weakness of the bloc members, and the superficial nature of bloc unity. The developing states are mostly former colonies that became independent as a result of international politics rather than their own state of readiness. These states suffer from chronic military and economic weakness, largely due to their underdevelopment.

The Third World is composed of a wide variety of nations with correspondingly diverse interests. While the members of the East and West had united when faced with a threat to their security, the members of the Third world had united in opposition to the disparity of wealth between North and South. However, given the extent of the diversity within the Third World, this accusation is in some ways a hollow argument. Although there is a great disparity between the richest of the industrialized and the poorest of the developing countries, the dividing line between the two groups is somewhat artificial. 
For example, it is true that Bhutan has a GNP per capita of only $\$ 70$ per year, while developed countries such as Italy have a per capita of $\$ 3440$ and the United States has an average income of $\$ 8520$. However, Third World countries like Venezuela and Argentina have incomes of close to $\$ 2000$ per year'. Economic wealth is a spectrum, not a dichotomy. Because of the many differences among the developing nations, the bond uniting the south is at times more words than deeds. The superficial nature of that bond was demonstrated during the global warming talks. Because the nations of the South span the spectrum of development, the global warming issue imposed unequal costs upon the bloc members. The differential costs of both the threat and the response to it, overcame the bond that united an already disparate group.

While the weakness of the developing nations precludes them from challenging the North either militarily or economically, the South does enjoy superiority in at least one area--number of countries. This numerical superiority becomes a factor in international organizations based on sovereign equality. Although the United Nations General Assembly had been controlled by a western majority in its early years, in 1960 that ability would pass to the developing world.

Although Third world control meant a greater forum for development issues, the change would have limited effect on world affairs. Because of the hortatory nature of General Assembly resolutions, in themselves they can accomplish few 
changes. Yet, although limited, the new power is still real. General Assembly resolutions help to set the international agenda and may, in some cases, serve as signposts of future international law.

The power of sovereign equality is dependent upon solidarity. Unity that is based solely on opposition may be relatively easy to create, however, it lacks the coherent set of ideas needed in order to become a viable political movement. The south coalesced into such a movement at the first meeting of the UNCTAD. It was during the negotiations of this conference that nations first aligned themselves into North and South. Led by Raul Prebisch, the developing nations adopted the structuralist argument as the ideology of their movement.

Structuralism justified Third World calls for financial aid and reforms of the economic system; the argument claimed that the current system favored the rich at the expense of the poor. Because of the Southern majority in the General Assembly, this cry for international equity would be eventually adopted in a series of resolutions called the New International Economic Order. Despite these resolutions, relatively little changed in the world economy.

The failure of the NIEO demonstrates that power, not morals, governs the operation of the international system. While the Third World power of sovereign equality can shape the international agenda, changes in international regimes 
require the cooperation of the powerful.

The power to set the agenda alone is insufficient, it must be supplemented by the ability to threaten a "bad" (power) or withhold a "good" (negative power). The negative power enjoyed by the South reflects its ability to influence an asset that the North deems valuable. By threatening to withhold its agreement to global environmental treaties, the South jeopardizes Northern efforts to control serious environmental problems. Negative power is the power to prevent a good rather than cause a "bad."

For this negative power to be present, three conditions must be met. First, whether a serious threat exists or not, the North must perceive it to be so. Second, policy decisions of the developing nations must have a substantial influence upon the threat. And finally, the South must maintain a solid front while negotiating with the North.

Both ozone depletion and global warming presented the South with the opportunity to take advantage of its negative power. In both cases, atmospheric pollution had threatened to cause serious and irreversible environmental damage; the future development of the South promised to exacerbate the problem. While the ozone depletion issue met the three requirements, global warming did not.

The North perceived a serious environmental threat in ozone depletion, while it failed to do so in the case of global warming. Although it seemed likely that the South 
could deliberately influence the CFC problem, global warming appeared less tractable to governmental solutions. Lastly, in contrast to ozone depletion, the global warming problem imposed differential costs upon bloc members. The innate diversity of the Third World overcame the bond that had united them. In order for negative power to be operable, all three conditions must be met. Thus, the south won significant concessions at Montreal but not at Rio.

Negative power has been of limited use to the South up until now, largely because at least one of these three conditions has not been met. In the future, certainly the first two requirements will be met. As the environmental pollution of the populous South becomes added to that of the North, global environmental problems will assume greater and greater centrality. Although the South certainly will not choose to forego development to save the environment, its choice of development paths can have a major impact. The third requirement, solidarity, is more difficult to predict. While future environmental problems will create opportunities for Southern power, its success will be dependent on the South's ability to arrive at a common negotiating position. Given the amount of diversity that exists in the South, it will have difficulty maintaining solidarity across the wide range of potential environmental problems. It seems likely that neither the power of sovereign equality nor negative power will rival the military and 
economic power of the North in the foreseeable future. However, both do represent real sources of power, and as such influence the course of international events. 
NOTES

1. See Chapter III, Table I. 


\section{BIBIIOGRAPHY}

Addo, Herb, ed.. Transforming the World-Economy. London: Hodder and Stoughton, 1984.

Alger, Chadwick F.. "The United States in the United Nations." International Organization 27 (Winter 1973): $1-23$.

Beckerman, Wilfred. "Economic Growth and the Environment: Whose Growth? Whose Environment?." World Development 20 (1992): $481-496$.

Bodansky, Daniel. "Draft Convention on Climate Change." Environmental Policy and Law 22 (February 1992): 5-14.

Christian Science Monitor 23 March, 1989.

Claude, Inis L.. Swords Into Plowshares. New York: Random House, 1964.

Corporaso, James A.. "The External Consequences of Regional Integration for Pan-European Relations." International Studies Quarterly 20 (September 1976): 342-392.

Craig, Gordon A. and Alexander L. George. Force and Statecraft. New York: Oxford University Press, 1990.

Covenant of the League of Nations.

Dean, Jr., Dale P. and John A. Vasquez. "From Power Politics to Issue Politics." Political Quarterly 29 (March 1976): 7-28.

Dickinson, Edwin Dewitt. The Equality of States in International Law. Cambridge: Harvard University Press: 1920.

East, Maurice, Stephen A. Salmore, Charles F.Hermann, eds.. Why Nations Act. Beverly Hills: Sage Publications, 1978 .

Ember, Lois R., Patricia L. Layman, Wil Lepkowski, and Pamela Zurer. "Tending the Global Commons." Chemical and Engineering News (November 24, 1986): $14-51$.

Feld, Werner and Robert Jordan, "Patterns of Decisionmaking in International Organizations," in Paul F. Diehl, ed., The Politics of International Organizations. Chicago: Dorsey Press, 1989: 117-134. 
Gardner, Richard N. In Pursuit of world Order. New York: Frederick A. Praeger, 1964.

Gardner, Richard N. and Millikan, Max F. The Global Partnership. New York: Frederick A. Praeger, 1968.

Garnham, David. "Power Parity and Lethal International Violence." Journal of Conflict Resolution 20 (September 1976): 379-393.

Gilpin, Robert. The Political Economy of International Relations. Princeton: Princeton University Press, 1987.

Ginsburg, Norton. Atlas of Economic Development. Chicago: University of Chicago Press, 1961. As cited in Russett.

Gosovic, Branislav. UNCTAD: Conflict and Compromise. Leiden, Neth.: A.W. Sijthoff, 1972.

Haas, Peter M. "Banning chlorofluorocarbons: epistemic community efforts to protect stratospheric ozone." International Organization 46 (Winter 1992): 189-224.

Hardin, Garrett, "The Tragedy of the Commons," Science 162 (December 3, 1968): 1243-1248.

Harris, Lillian Craig and Worden, Robert L., eds.. China and the Third world: Champion or Challenger?. Dover: Auburn House Publishing Company, 1986.

Hart, Jeffrey. "Three approaches to the measurement of power in international relations." International Relations 30 (Spring 1976): 289-305.

Hatch, Michael T.. "Domestic Politics and International Negotiations: the Politics of Global Warming in the United States." Journal of Environment and Development 2 (Summer 1993): 1-39.

Hayes, Peter and Kirk Smith, eds.. The Global Greenhouse Regime: Who Pays. Tokyo: United Nations University Press, 1993.

Helleiner, G.K.. The New Global Economy and Developing Nations. Aldershot, Eng.: Edward Elgar, 1990.

Hobbes, Thomas. Leviathan. Indianapolis: Bobbs-Merrill Co., 1958.

Holsti, K.J.. International Politics: A Framework for 
Analysis. Englewood Cliffs, NJ:Prentice-Hall, 1972. As cited in Caporaso, James A.. "The External Consequences of Regional Integration for Pan-European Relations," International studies Quarterly 20 (September 1976).

Homer-Dixon, Thomas F.. "Environmental Changes as Causes of Acute Conflict." In Conflict After the Cold War, ed. Richard K. Betts, 425-441. New York: Macmillan Publishing Company, 1994.

Intergovernmental Panel on Climate Change. IPCC First Assessment Report: Overview and Policymakers Summaries, (1990).

Jackson, Robert. "Quasi-states, dual regimes and neoclassical theory: international jurisprudence and the Third World," International Organizations 41 (August 1987): 519-549.

James, Alan. "The equality of states: contemporary manifestations of an ancient doctrine." Review of International Studies 18 (October 1992): 377-391.

Kaplan, Morton. System and Process in International Politics. New York: John Wiley \& Sons, 1957.

Keohane, Robert 0.. After Hegemony. Princeton: Princeton University Press, 1984.

Keohane, Robert 0., ed.. Neorealism and Its Critics. New York: Columbia University Press, 1986.

Keohane, Robert $0 .$, and Joseph S. Nye. Power and Interdependence 2nd ed.. Boston: Little, Brown, 1989.

Klein, Robert A.. Sovereign Equality Among States: The History of an Idea. Toronto: University of Toronto Press, 1977.

Kooijmans, Pieter Hendrick. The Doctrine of the Legal Equality of States. Leiden: A.W. Sijthoff, 1964 .

Krasner, Stephen. Structural Conflict: The Third world Against Global Liberalism. Berkeley: University of California Press, 1985.

Lapidoth, Ruth. "Sovereignty in Transition," Journal of International Affairs 45 (Winter 1992): 325-346.

Los Angeles Times 29 June, 1990.

Lundestad, Geir. Major Developments in International 
Politics 1945-1986. Oslo: Norwegian University Press, 1986.

Magraw, Daniel Barstow. "Legal Treatment of Developing Countries." Colorado Journal of International Environmental Law and Policy 1, (Summer 1990): 69-99.

Maslow, A.H.. Motivation and Personality. New York: Harper \& Brothers, 1954.

Mensah, Chris K. "The Role of the Developing Countries," in Luigi Campiglio, ed.. The Environment After Rio.

London: Graham \& Trotman/Martinus Nijhoff, 1994, 33-54.

Milier, J.D.B.. "The Sovereign State and Its Future." International Journal 39 (Spring 1984): 284-301.

Modelski, George. World Power Concentrations. Morristown: General Learning Press, 1974.

Morgenthau, Hans J., Kenneth W. Thompson. Politics Among Nations 6th ed.. New York: Alfred A. Knopf, 1985.

Morrissette, Peter. "The Montreal Protocol: Lessons for Formulating Policies for Global Warming." Policy Studies Journal 19, (Spring 1991): 152-161.

Morrissette, Peter M. and Andrew J. Plantinga. "Global Warming: A Policy Review." Policy Studies Journal 19 (Spring 1991): 163-172.

New York TImes 21, 25 March, 1988, 30 June, 1990, 8 May, 5, 10 June 1992.

Ntambirweki, John. "The Developing Countries in the Evolution of an International Environmental Law." Hastings International and Comparative Law Review 14 (Fall 1990): 905-928.

Peterson, M.J.. The General Assembly in World Politics. Boston: Allen \& Unwin, 1986.

Riggs, Robert E., and Jack C. Plano. The United Nations. Pacific Grove, CA: Brooks/Cole Publishing, 1988.

Rochester, J. Martin. Waiting for the Millennium. Columbia, S.C.: University of South Carolina Press, 1993.

Reubens, Edwin P., ed.. The Challenge of the New International Economic Order. Boulder, Colo.: Westview Press, 1981. 
Rosecrance, Richard. America as an Ordinary Country.

Ithaca: Cornell University Press, 1976.

- International Relations: Peace or War?. New York: MCGraw-Hill, 1973.

Rothstein, Robert. Alliances and Small Powers. New York: Columbia University Press, 1968.

- The Weak in the world of the strong. New York: Columbia University Press, 1977.

Russett, Bruce M.. "Components of an operational theory of international alliance formation." Journal of Conflict Resolution 12 (September 1968): 285-301.

Sauvant, Karl P.. The Group of 77: Evolution, Structure, and Organization. New York: Oceana Publications, 1981.

- The Group of 77: The Third world Without

Superpowers. New York: Oceana Publications, 1981.

Sebenius, James $\mathrm{K}$. "Designing Negotiations Toward a New Regime." International Security 15 (Spring 1991): 110147 .

Simon, Jeffrey. NATO-Warsaw Pact Force Mobilization. (Wash. D.C.: National Defense University Press, 1988.

Singer, Marshall R.. Weak States in a World of Powers. New York: The Free Press, 1972.

South, 102, editorial, "The hole in the ozone logic," (April 1989): 9 .

Spanier, John. Games Nations Play. New York: Praeger Publishers, 1972 .

Spero, Joan Edelman. The Politics of International Economic Relations. New York: St. Martin's Press, 1985.

Speth, James Gustave. "A Post-Rio Pact. " Foreign Policy 88 (Fall 1992): 145-161.

Stein, Arthur A.. Why Nations Cooperate. Ithaca: Cornell University Press, 1990.

Sullivan, Michael P.. Power in Contemporary International Politics. Columbia,S.C.: University of South Carolina Press, 1990.

Taylor, Charles L., Michael C. Hudson. World Handbook of 
Political and Social Indicators 2nd ed.. New Haven: Yale University Press, 1972.

Thompson, William and David Rapkin. "Bipolarity and Bipolarization." Journal of Conflict Resolution 23, (June 1979) : 261-295.

Tucker, Robert W.. The Inequality of Nations. New York: Basic Books, Inc, 1977.

United Nations. UNCTAD, United Nations Conference on Trade and Development. Basic Documents on Its Establishment and Activities. U.N. Pub. 66.I.14.

United Nations Charter.

United States Arms Control and Disarmament Agency, World Military Expenditure Time Series, 1961-1970, Computer file, (Ann Arbor, MI: Inter-University Consortium for

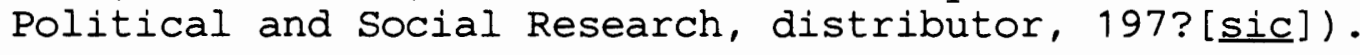

de Vattel, Emeric. Le droit des gens ou principes de la loj naturelle appliques a la conduite et aux affaires des nations et des souvervains. New ed. by Joseph Chitty, Esq, Philadelphia: T \& J Johnson, 1870.

Wagner, R. Harrison. "What was bipolarity," International Organizations 47 (Winter 1993): 76-106.

Wall Street Journal 3, 23 June, 1992.

Waltz, Kenneth. Theory of International Politics. New York: McGraw-Hill, 1979.

Ward, Michael D., Lewis L. House. "A Theory of the Behavioral Power of Nations," Journal of Conflict Resolution 32 (March 988): 3-36.

Washington Post, 7 March, 1989.

Williams, Gwyneth. Third World Political Organizations. Montclair, NJ: Allanheld, Osmun \& Co, 1981.

Williams, Marc. "Re-articulating the Third World Coalition." Third World Quarterly 14 (1993): 7-29.

- Third World Cooperation: The Group of 77 in UNCTAD. London: Pinter Publishers, 1991.

Willetts, Peter. The Non-Aligned Movement: The Origins of the Third World Alliance. London: Frances Pinter Ltd., 1978 . 
World Resources Institute. Report by the World Resources Institute and International Institute fpr Environment and Develooment. (New York: Basic Books, 1992).

Zamora, Stephen. "Voting in International Economic Organizations." American Journal of International Law 73 (July, 1980): 566-610.

Zartman, I William. Positive Sum: Improving North-South Negotiations. New Brunswick: Transaction Books, 1987. 